Retirement Age across Countries: The Role of Occupations

Philip Sauré and Hosny Zoabi

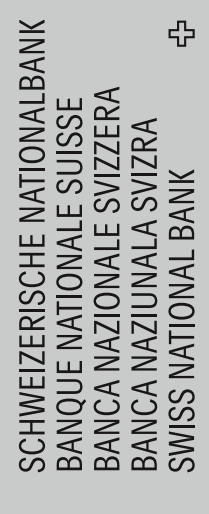


The views expressed in this paper are those of the author(s) and do not necessarily represent those of the Swiss National Bank. Working Papers describe research in progress. Their aim is to elicit comments and to further debate.

\section{Copyright $\odot$}

The Swiss National Bank (SNB) respects all third-party rights, in particular rights relating to works protected by copyright (information or data, wordings and depictions, to the extent that these are of an individual character). SNB publications containing a reference to a copyright ( $\odot$ Swiss National Bank/SNB, Zurich/year, or similar) may, under copyright law, only be used (reproduced, used via the internet, etc.) for non-commercial purposes and provided that the source is mentioned. Their use for commercial purposes is only permitted with the prior express consent of the SNB.

General information and data published without reference to a copyright may be used without mentioning the source.

To the extent that the information and data clearly derive from outside sources, the users of such information and data are obliged to respect any existing copyrights and to obtain the right of use from the relevant outside source themselves.

\section{Limitation of liability}

The SNB accepts no responsibility for any information it provides. Under no circumstances will it accept any liability for losses or damage which may result from the use of such information. This limitation of liability applies, in particular, to the topicality, accuracy, validity and availability of the information.

ISSN 1660-7716 (printed version)

ISSN 1660-7724 (online version)

๑ 2012 by Swiss National Bank, Börsenstrasse 15, P.0. Box, CH-8022 Zurich 


\title{
Retirement Age across Countries: The Role of Occupations*
}

\author{
Philip Sauré ${ }^{\dagger}$ \\ First draft: September 2011 \\ This draft: April 2012
}

Hosny Zoabi ${ }^{\ddagger}$

\begin{abstract}
Cross-country variation in average retirement age is usually attributed to institutional differences that affect individuals' incentives to retire. We suggest a different approach. Since workers in different occupations naturally retire at different ages, the composition of occupations within an economy matters for its average retirement age. Using U.S. data we infer the average retirement age by occupation, which we then use to predict the retirement age of 38 countries according to the occupational composition of these countries. Our findings suggest that the differences in occupational composition explain up to $39.2 \%$ of the observed cross-country variation in retirement age.
\end{abstract}

Keywords: Retirement Age, Occupational Distribution, Cross-Country Analysis.

JEL Classifications: J14, J24, J26, J82.

*The views expressed in this paper are the authors' views and do not necessarily represent those of the Swiss National Bank.

${ }^{\dagger}$ P. Sauré, Swiss National Bank, Boersenstrasse 15, CH-8022 Zurich, Switzerland. E-mail: philip.saure@snb.ch.

${ }^{\ddagger}$ H. Zoabi, The Eitan Berglas School of Economics, Tel Aviv University, P.O.B. 39040 Ramat Aviv, Tel Aviv 69978, Israel. E-mail: hosnyz@post.tau.ac.il. 


\section{Introduction}

Long-standing trends towards earlier retirement and higher life expectancy jeopardize the sustainability of existing pension systems and fuel academic and political discussions. Lifting the retirement age by a year or two is often proposed as a method for curbing the resulting costs of Social Security systems. While such proposals face strong political resistance, they appear rather modest in comparison with existent cross-country differences in the effective average retirement age. ${ }^{1}$

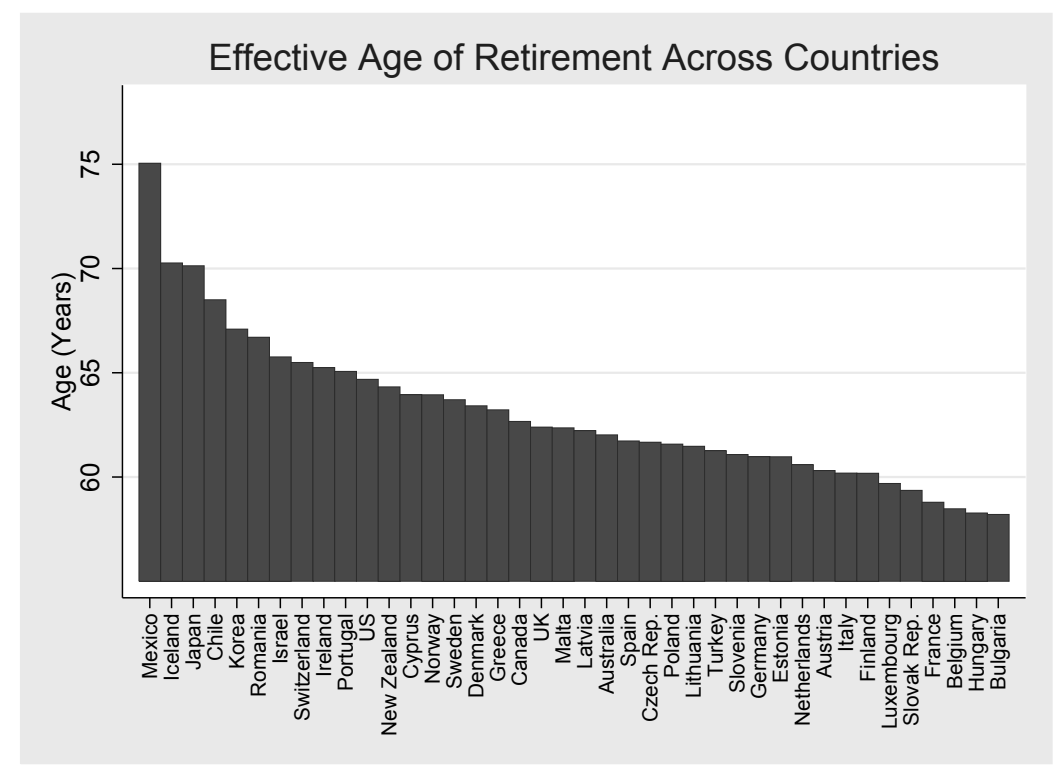

Figure 1: The effective age of retirement of male working populations across 40 countries for the year 2000. Source: Organization for Economic Cooperation and Development (OECD), based on national labor force surveys.

Figure 1 exhibits the huge cross-country variations in the retirement age of male working populations. The numbers vary widely between the poles of Mexico (75) and Bulgaria (58.2). Existing research has used this cross-country variation to shed light on the determinants of retirement decisions, commonly highlighting individual incentives related to Social Security and pension systems. For example, Gruber and Wise (1998) argue that Social Security programs provide the prime determinants for retirement decisions, writing that

\footnotetext{
${ }^{1}$ Throughout the paper, we will use the term 'effective retirement age' to refer to the age of retirement actually observed or reported by our different data sources.
} 
The collective evidence for all countries combined shows that statutory socialsecurity eligibility ages contribute importantly to early departure from the labor force (p. 161).

In the present paper we propose a new explanation for the cross-country variation in the age of retirement. Our explanation relies on the observation that individuals in different occupations retire at different ages. Based on this observation, we argue that an economy's composition of occupations matters for its average effective retirement age. Starting from this simple idea, we build a predictor of an economy's average retirement age solely from its occupational composition. It turns out that this predictor performs well in explaining the cross-country differences in the effective retirement age.

If the occupational distribution is to impact a country's average retirement age, retirement age must differ across occupations. Figure 2 shows that within the U.S., the average effective age of retirement indeed varies over 179 occupations. $^{2}$ For example, the average age of retirement of Psychologists is 71, while Airplane pilots retire around the age of 60.2 (see Table A1 in the Appendix). At least part of these differences are likely to be explained by intrinsic characteristics of the corresponding occupations such as physical requirements or the pace at which job-specific knowledge depreciates.

Clearly, a country whose working population is mostly engaged in occupations characterized by early retirement age can be expected to have a lower average retirement age than a country whose working population is more concentrated at the other end of the occupational spectrum. By a simple composition effect, the occupational distribution potentially impacts a country's average retirement age. The composition of occupations, however, can be relevant for cross-country differences in the retirement age only if the underlying occupational distribution varies across countries. Figure 3 shows that, in fact, large cross-country differences in the occupational distribution exist within a sample of 44 countries. The figure plots the share of employment for male working population in these countries across nine broad one-digit of the International

\footnotetext{
${ }^{2}$ We use Current Population Survey (CPS) data from Integrated Public Use Microdata Series (IPUMS). See King, Ruggles, Alexander, Flood, Genadek, Schroeder, Trampe and Vick (2010). The method used to compute the average retirement age by occupation is described below. We obtained observations for 179 of the 263 occupation classes defined by the Census Bureau.
} 


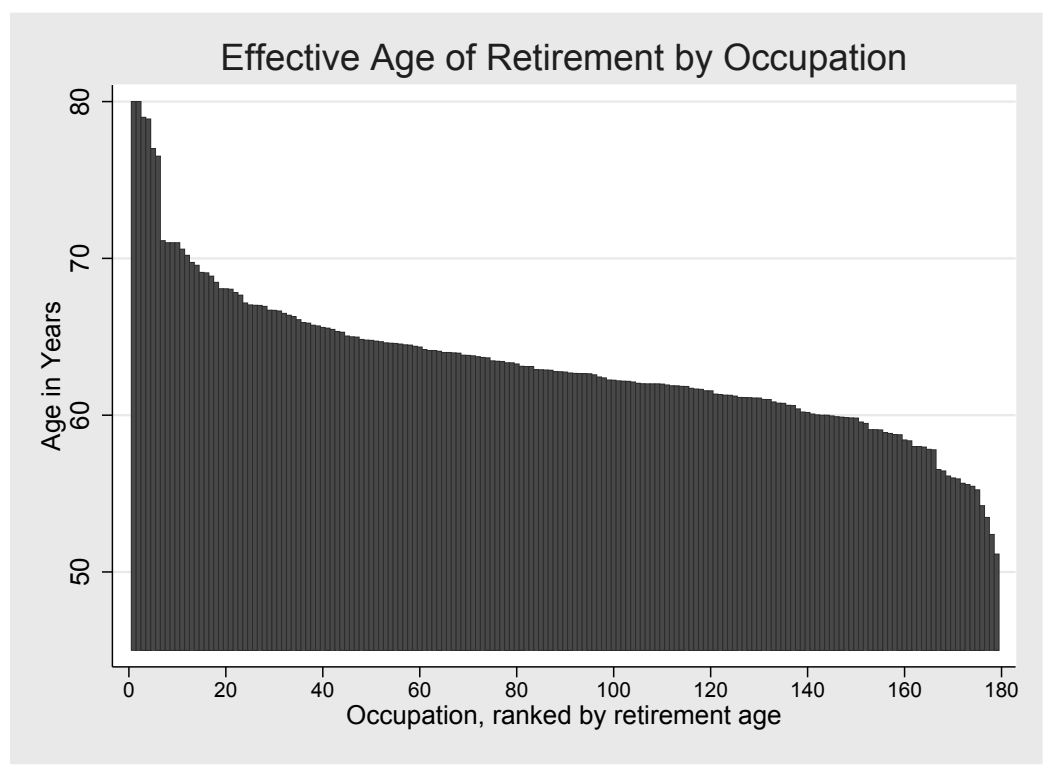

Figure 2: The effective age of retirement of male working populations in the U.S. across 179 occupations during the period 1990 - 2010. Data are based on census classification scheme (3 digit). Source: authors' calculations from IPUMS-CPS.

Standard Classification of Occupations (ISCO-88). ${ }^{3}$ Each of the small dots represents the employment share of a country in the respective occupation; the larger dots represent unweighted country averages. While the cross-country average employment share is highest for Craft and related and lowest for Clerical support workers, the figure shows that occupation shares are widely dispersed across countries. ${ }^{4}$

To assess how occupational distributions affect average retirement ages we procede in two steps. First, we use U.S. data to infer the average retirement age by occupation. Second, for any given economy, we predict its average retirement age by the weighted average of occupational retirement age from the U.S.; the weights are the economy's occupational employment shares. The result of this out of sample prediction will be

\footnotetext{
${ }^{3}$ The countries for which occupation data with ISCO-88 classification exist are: Aruba, Austria, Belgium, Bulgaria, Cyprus, Czech Republic, Denmark, Ecuador, Egypt, Estonia, Finland, France, Gabon, Germany, Greece, Hong Kong, China, Hungary, Iceland, Iran, Ireland, Italy, Latvia, Lithuania, Luxembourg, Mauritius, Mongolia, Netherlands, Pakistan, Philippines, Poland, Portugal, Seychelles, Slovakia, Slovenia, Spain, South Korea, Sweden, Switzerland, Thailand, Uganda, Ukraine, and the United Kingdom.

${ }^{4}$ The two outliers for 'Skilled agricultural, forestry and fishery workers' (Agriculture in the figure) are Mongolia (with a share of $47.9 \%$ ) and Thailand (38\%); South Korea has the highest share for 'Plant and machine operators, and assemblers' (39.8\%).
} 


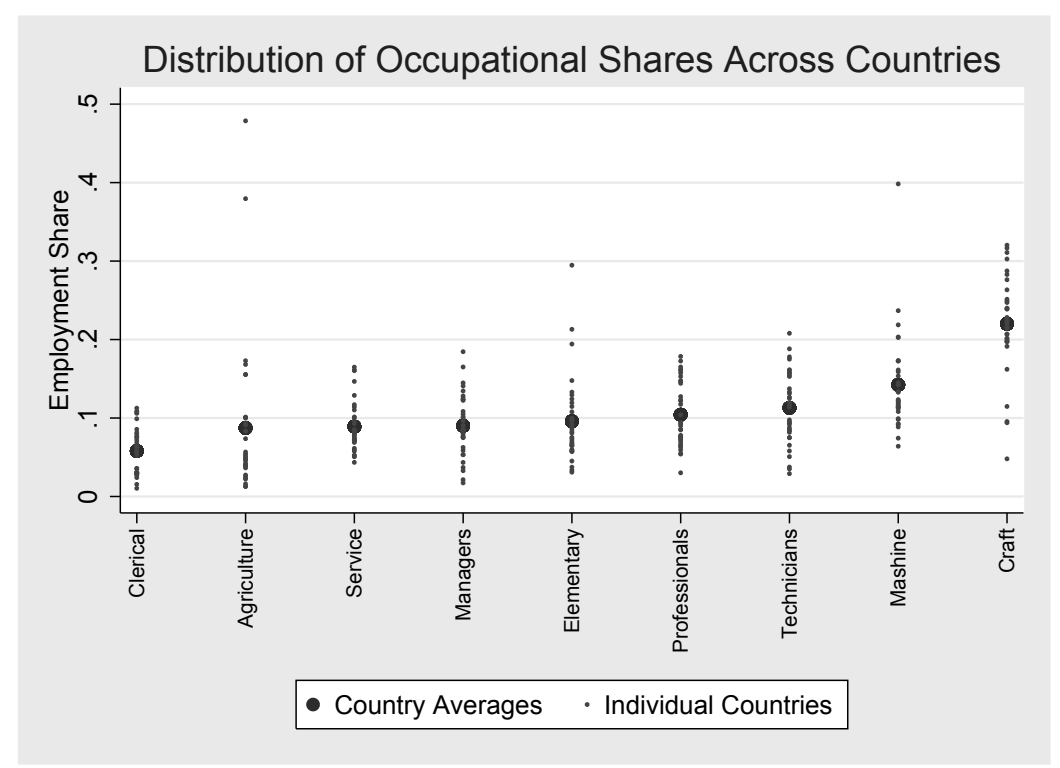

Figure 3: The share of employment of male working population across 34 countries. Data are based on ISCO-88 classification scheme. Source: ILO.

called the raw predictor. Finally, we examine to what extent this information can explain the variation in the age of retirement across the globe. Conceptually, we try to explain differences across countries using differences across Americans.

We compare our raw predictor with the effective retirement age in two different samples. First, we start with the OECD sample that includes a set of homogenous countries. Restricting our cross-country analysis to the year 2000, we are left with 28 advanced countries (excluding the U.S.). A variance decomposition shows that our raw predictor explains $10.3 \%$ of the cross-country variation in the effective age of retirement. Second, we extend the range of countries to include not only developed countries but also developing ones. Our sample grows to 38 countries. In this extended sample a variance decomposition shows that our prediction explains about $17 \%$ of the variation in the effective age of retirement across countries.

We next surmise that our raw predictor might be improved by accounting for the possibility that external factors may influence absolute differences in the age of retirement across occupations but preserve the relative differences. For example, the inevitable loss of information in the crosswalk of occupation classifications we use tends to blur the differences in the corresponding retirement ages and to compress the distribution 
of retirement ages. ${ }^{5}$ To correct for these effects, we conduct a linear transformation of our raw predictor. Specifically, we run a regression to estimate the way our raw predictor correlates with the effective age of retirement. In these regressions we obtain an $R^{2}$ of $28 \%$ for the sample of OECD countries and an impressive $39.2 \%$ for the extended sample. These numbers stongly indicate that occupational distribution is an important factor in explaining differences in the age of retirement across countries.

We notice that in the OECD sample the estimated coefficient, which is significant at the one percent level, is 4.7 and significantly above one (compare Table 2, Column I). This finding requires a word of explanation. One possible explanation is the effect of the crosswalk of occupation classifications we need to use to map 179 occupation classes from the U.S. data into the 43 classes of our cross-country data. As pointed out above, the loss of information tends to blur the differences of retirement ages and compress the distribution of retirement ages, which results in a steeper estimated coefficient. ${ }^{6}$ Another possible explanation for the high coefficient relies on the differences in the Social Security system. Thus, the U.S. has a relatively lean Social Security system compared to most other OECD countries, which may well compress the occupational distribution of retirement ages in the U.S. Indeed, it is possible that in economies with learn Social Security programs virtually everybody is working up to the mandatory retirement age, while generous Social Security programs induce workers of some occupations - e.g. those characterized by high levels of human capital depreciation - to retire relatively early. When the impact of Social Security programs on the age of retirement differs across occupations, the generous systems will result in a more dispersed occupational retirement ages, thus explaining that the size of the estimated coefficient exceeds one. ${ }^{7}$ Indeed, when extending the sample to include developing countries characterized by lean Social Security and welfare programs the magnitude of the coefficient drops to 3.2

\footnotetext{
${ }^{5}$ Consider the extreme case of a crosswalk mapping all U.S. classes into only one single class. The predicted retirement ages based on this crosswalk would be constant across countries, hence totally compressing the cross-country difference in the raw predictor.

${ }^{6}$ In the extreme case as differences of occupational retirement age vansih, the predictor collapses to one number and the slope of the fit approaches infinity.

${ }^{7}$ This explanation is reminiscent of the one Ljungqvist and Sargent (1998) provide for the long-term unemployment in welfare states during the 1980s. The authors argue that without technological progress unemployed workers easily get back into employment even with generous unemployment benefits. However, in periods of fast technological progress the skill of laid-off workers quickly becomes obsolete and generous unemployment compensations prevent them from accepting new job offers.
} 
(Table 3, Column II).

We do not ignore that the literature on retirement decisions typically focuses on financial incentives, in particular on those connected to Social Security and pension systems. We therefore examine whether the predictive power of occupational compositions is affected by these policy variables. To this end, we run simple multivariate OLS regressions of the observed average retirement age on our raw predictor and number of policy variables related to retirement incentives. The coefficient on our raw predictor of retirement remains highly significant and positive. The inclusion of the policy variables increases the $R^{2}$ from $47 \%$ to up to $84 \%$ in our OECD sample and from $39 \%$ to $75 \%$ in our extended sample. Thus, financial incentives and occupational compositions jointly explain the major part of the variation in the effective age of retirement.

Finally we follow the literature and control for additional variables that might affect the age of retirement such as per-capita GDP, life expectancy, the share of urban population and average schooling and find that the coefficient on our raw predictor is intact in terms of magnitude and statistical significance.

With the current study we establish a clear link between occupations and the age of retirement. We feel, however, the urge to explicitly spell out that we do not identify a country's occupational distributions as the cause for its average age of retirement. Indeed, one may think of mechanisms that establish a causal link in the reverse direction. For example, a general mandatory retirement age will affect some occupations more than others ${ }^{8}$ or Social Security systems may systematically discriminate between occupations. Both of these policies distort the relative occupational retirement ages, and therefore the occupations' relative productivities. The resulting impact on a country's comparative advantage generates international specialization and hence determines the country's occupational distribution. In these examples, policies causally affect the occupational distribution via their effect on the age of retirement.

While in these examples government policies determine the occupational distribution, one may even go one step further and argue that the very government policies, in turn,

\footnotetext{
${ }^{8}$ Assuming that the ages reported in Table $\mathrm{A} 3$ in the appendix are undistorted, mandatory retirement at age 65 would not affect Chemists who retire at 62.9 but forces Clergymen who retire at 68 to retire earlier (codes 7 and 9).
} 
are shaped by a country's occupational distribution. Indeed, if the number of workers in a specific occupation grows and becomes politically relevant, the resulting political pressure may induce changes of the Social Security system that favor these specific occupations. By endogenizing Social security systems, this example shows that individual retirement incentives, which are usually taken as the key determinant of retirement decisions, are not the starting point of a causal chain. Instead, they may well be shaped by the occupational distribution, making the latter the deep reason for policies.

In sum, our study neither establishes causality nor does it claim to do so. Nevertheless, we argue that it adds to the literature in some relevant dimensions. At the very least, our results show that a strong link exists between occupations and the retirement age and that this link is relevant for macroeconomic aggregates. This observation implies that there is high potential for studies that investigate the occupation specific retirement incentives and that retirement studies ignoring occupational dimensions are likely to miss part of the variation.

Moreover, our methodology provides a natural benchmark of a country's retirement age that helps to assess common arguments in on-going political debates. For example, Greece, Spain and Portugal are recently accused of retiring too early. For example, the German chancellor Angela Merkel requested that people in Southern Europe should not 'be able to retire earlier than in Germany'. This argument seems far-fetched when observing that the effective age of retirement in Greece exceeds that of Germany by about 27 month. Indeed, referring to these inconsistencies, the Financial Times Deutschland writes that "Merkel's push for a comparison here is both unnecessary and absurd". 9 However, when accounting for differences in occupational compositions between the two countries, the picture is somewhat altered. Greek excess retirement age over the German one shrinks considerably to less than 20 months. Moreover, when refining the predicted occupational distribution with a linear fit the overall picture turns upside down: Germans retire ten months later than Greeks. ${ }^{10}$

We now provide a short overview over the three broad literatures our paper relates to: first, retirement incentives and decisions, second, the differences in retirement age across

\footnotetext{
${ }^{9}$ See http://www.spiegel.de/international/europe/0,1518,763639,00.html.

${ }^{10}$ It is important to stress, however, that this explanation, however, does not apply in the cases of Portugal, Spain and Italy.
} 
occupations and third, the determinants of a country's distribution of occupations.

\subsection{Social Security Program Incentives}

Most of the existing literature attributes the variation in the age of retirement to crosscountry differences in the incentives that individuals face when deciding on their retirement age. These incentives are driven mainly by Social Security regulations (Gruber and Wise 1998, Gruber and Wise 2004), Social Security benefit rules and private pension (Mitchell and Fields 1984) or a mix of state, private pension provision and wealth (Blundell, Meghir and Smith 2002).

The literature also diversifies in estimating these incentives. Beginning with defining these incentives by simply the level of retirement wealth with one additional year, the literature has moved to focus on the entire evolution of future wealth (Stock and Wise 1990, Coile and Gruber 2007). In line with this literature, retirement peaks at both ages 62 an 64 are attributed to Social Security rules (Rust and Phelan 1997, Gustman and Steinmeier 2005). ${ }^{11}$ Moving to the incentives within the household, Coile (2004) find that men and women are similarly responsive to their own financial incentives and that men are very responsive to their wives' financial incentives.

Closer to our paper, which focuses on cross-country variation in the age of retirement, the literature also attributes such a variation to the institutional differences that affect individuals' incentives to retire. In an international comparison, Gruber and Wise $(1999,2004)$ examine the effect of Social Security systems on male retirement and find that in each country retirement peaks at exactly the ages at which the retirement incentives are strongest. Bloom, Canning, Fink and Finlay (2009) analyze panel data for 40 countries over the period of 1970-2000 and find that Social Security reforms have substantially increased the labor supply of older men. It is important to note, however, that the literature does not unanimously suggest that Social Security has a significant impact on retirement (Krueger and Pischke 1992, Burtless 1986).

\footnotetext{
${ }^{11}$ The literature proposes other determinants for the age of retirement. In explaining the rise of retirement during the $20^{\text {th }}$ century, Kalemli-Ozcan and Weil (2010) argue that the reduction in mortality induces individuals to plan and save for retirement as the risk of dying before enjoying the planned leisure declines.
} 


\subsection{Differences in the Age of Retirement across Occupations}

Differences in rates of human capital depreciation is an obvious reason why workers across occupations retire at different ages. Rosen (1975) made the first attempt to distinguish between two types of human capital deterioration. The first is knowledge obsolescence. This aspect of human capital refers to the fact that stocks of productive knowledge available to society change over time. The second type is general health deterioration with physiological factors such as ageing, injuries or illnesses depreciating mental and physical capacities.

The economic literature abounds on knowledge obsolescence. The growth literature employs this factor to explain the transition from stagnation to growth (Galor and Weil 2000, Galor 2005). However, knowledge obsolescence can differ across industries or occupations and can affect older workers differently from younger ones. While Ahituv and Zeira (2000) argue that technological progress induces early retirement by eroding technology-specific human capital in the economy as a whole, Allen (2001) reports direct evidence on how technological change differently affects wage structure in different industries and Aubert, Caroli and Roger (2006) find evidence that in innovative firms, the wage bill share of older workers is lower. Using occupational data, Bartel and Sicherman (1993) support the hypothesis that an unexpected change in the rate of technological change will induce older workers to retire sooner because the necessary retraining will be an unattractive investment. ${ }^{12}$ Given that the pace of technological progress varies across occupations, the evidence just described implies that the age of retirement differs across occupations.

The economic literature focuses on health depreciation as well. Besides financial characteristics and labor market conditions, Quinn $(1977,1978)$ analyze the impact of job characteristics such as undesirable working conditions, physical demands and necessary aptitudes on the decision to retire and find that health status and working conditions are important determinants of early retirement among white men in the U.S. Mitchell, Levine and Pozzebon (1988) and Filer and Petri (1988) provide evidence that retirement patterns differ by occupation and industry and found that the major factors

\footnotetext{
${ }^{12}$ For a further discussion on the impact of the introduction of new technologies on wages structure see Bartel and Lichtenberg (1987), Mincer and Higuchi (1988) and Friedberg (2003).
} 
affecting retirement are job satisfaction, workplace injury or illness, and job productivity. Finally, Burtless (1987) observes that men in professional, managerial, clerical and sales occupations tend to work the longest, followed by those working in crafts, operatives and service occupations, while farm and non-farm laborers tend to leave work the youngest. ${ }^{13}$

The literature just described strongly suggests that differences in the age of retirement across occupations are important. The link between occupations and the aggregate retirement age differences however have not been addressed explicitly A noteworthy exception to the above mentioned literature is Coile and Gruber (2007), who find that industry and occupation do not show a particularly strong retirement age pattern, with the exception of lower retirement ages in two broadly defined occupations: armed forces and cleaning and building services. In their regressions, Coile and Gruber (2007) control for thirteen major industry dummies and seventeen major occupation dummies. These aggregated data, however, hide differences in the age of retirement across narrowly defined industries and occupations. Table A1 in the Appendix shows, for example, that while farm foremen retire at age 61.7 , farm laborers retire at age 68.5 . Contrary to Coile and Gruber (2007), we use highly detailed occupation data and find that the age of retirement significantly varies across occupations. ${ }^{14}$

While the specific drivers of the different retirement ages across occupations constitute an interesting field of study, they are independent of the argument we advance in the present paper. Our approach simply relies on the fact that these differences across occupations exist and the observation that they impact the average retirement age of an economy through its occupational composition.

\footnotetext{
${ }^{13}$ The economic literature is complemented by sociological and medical literatures. Hayward (1986) and Hayward, Grady, Hardy and Sommers (1989b) find that occupational physical demands to be a direct factor in the decision to retire. Haveman, Wolfe and Warlick (1985) discover that occupational differences in the probabilities of death and disability directly affect differences in the probability of retirement. Hayward, Hardy and Grady (1989a) show that professionals, managers, and salesmen have relatively low rates of retirement. Hurd and McGarry (1993) find that other occupation characteristics such as job flexibility are significant to the retirement decision, as an aging worker who wants to gradually reduce working hours may retire earlier if prevented from doing so than he would were such constraint removed. Finally, Karpansalo, Manninen, Lakka, Kauhanen, Rauramaa and Salonen (2002) show that physical workload increases the probability of retirement on a disability pension especially due to musculoskeletal disorders.

${ }^{14}$ To verify that our results are not driven by the armed forces, we exclude this occupation and find that all of our results are intact.
} 


\subsection{Differences in the Distribution of Occupations across Countries}

Economic development and international trade are typically thought of as the two major determinants of the cross-country differences in the occupational distribution.

On the one hand, economic development and the adoption of new technologies obviously impacts the labor market and the composition of tasks and diversifications. Intuitively, the share of science and engineering professionals should be higher in more advanced economies, while the opposite is true for subsistence farmers. Imbs and Wacziarg (2003) show that economies on a development trajectory tend to undergo various stages of diversification within the spectrum of industries. They provide no specific observations regarding which sectors dominate at what level of development, but clearly document a strong impact of development on the distribution of labor across sectors and across occupations. Relatedly, Autor and Dorn (2009) and Acemoglu and Autor (2011) find that due to technical change occupations that were in the top and bottom of the 1980 wage distribution expanded relative to those in the middle. In line with these findings Goos, Manning and Salomons (2008) report that, for many European countries, disproportional growth in high paying occupations expanded relative to middle-wage occupations.

On the other hand, trade liberalization -inducing international specialization- affects the composition of industries and occupations. Empirical studies assessing the impact of trade on labor migration, employment and job creation and destruction have traditionally looked at industry employment (Revenga 1992, Levinsohn 1999, Amiti and Wei 2009). Recently, Schott $(2003,2004)$ has shown, however, that a large part of the factor reallocation takes place within industries. This observations implies that previous work measuring inter-industry labor migration most likely missed large parts of the effect of trade on labor markets and further suggests to look on other dimensions of the labor market such as occupations. A number of papers investigate the effect of import competition on employment along the occupational dimension. Ebenstein, Harrison, McMillan and Phillips (2011) construct an occupation-specific measure of import penetration and measure the effect of trade on U.S. employment. The authors report that "international trade has had large, significant effects on occupation-specific wages". In line 
with Schott $(2003,2004)$, the authors argue that "[t]he downward pressure on wages due to import competition has been overlooked because it operates between and not within industries". Focusing on the effect of trade in services, Liu and Trefler (2008) document that in the U.S., the export of services to China and India (or "inshoring" in the authors' terminology) has negative, albeit small, effects on the probability of switching occupations (at the 4-digit classification level). These findings demonstrate a measurable impact of trade on the distribution of occupations.

With regard to the present paper's argument, the fundamental source of cross-country differences in occupational distribution is largely irrelevant. Our main point is that these underlying factors may very well affect an economy's retirement age. ${ }^{15}$

In the remainder of this paper, section 2 describes our empirical strategy, data and results and section 3 concludes.

\section{Empirics}

\subsection{General Method}

To what extent can cross-country differences in the occupational composition explain cross-country differences in the average effective retirement age? To address this question we observe that the average retirement age in country $c$, ret $t_{c}$, can be written as:

$$
\text { ret }_{c}=\sum_{o \in O} w_{c, o} \text { ret }_{c, o} .
$$

where, $w_{c, o}$ is the employment share of occupation $o \in O$ in country $c \in C$ and ret $_{c, o}$ is the average retirement age of occupation $o$ in country $c$.

We define now ret re $_{o}$ as the retirement age of occupation $o$ in a hypothetical undistorted economy. By definition, ret t $_{o}$ is only driven by intrinsic factors of the corresponding

\footnotetext{
${ }^{15}$ Of course, one might flip the question and ask to what extent the occupational composition explains a country's comparative advantage and the patterns of specialization. We do not further explore this interesting aspect in the present paper. We need to stress that we do not claim to establish causality in either direction between our predicted and the effective age of retirement.
} 
occupation. With this definition we can write the identity

$$
\operatorname{ret}_{c} \equiv \sum_{o \in O} w_{c, o} \text { ret }_{o}+\sum_{o \in O} w_{c, o}\left(\text { ret }_{c, o}-\text { ret }_{o}\right)
$$

Equation (2) defines a decomposition of the average retirement age. The first term on the right hand side represents the contribution of the occupational composition to the retirement age, assuming that individual retirement decisions depend only on intrinsic characteristics of their occupations. The second term consists of the weighted deviations of the occupational retirement ages from the exogenous ones.

Writing now $w_{o}$ for the employment shares of our hypothetical undistorted economy and ret for its average retirement age, we have

$$
\text { ret }_{c}-r e t \equiv \sum_{o \in O}\left(w_{c, o}-w_{o}\right) \operatorname{ret}_{o}+\sum_{o \in O} w_{c, o}\left(\text { ret }_{c, o}-\text { ret }_{o}\right)
$$

An analysis that addresses cross-country differences in retirement age, ret $_{c}$ but ignores intrinsic differences across occupations implicitly assumes that ret $t_{o}$ is constant in $o$ and will therefore explain the cross-country variance exclusively through the second term in (2). In the present paper, we pursue the opposite approach and specifically focus on the occupational differences of retirement ages. To this aim, we define the relevant term:

$$
\overline{r e t}_{c}=\sum_{o \in O} w_{c, o} r e t_{o}
$$

This expression represents the retirement age in country $c$ if it were determined solely by intrinsic characteristics of the occupations. Then we estimate the following econometric model

$$
\text { ret }_{c}=\delta_{1} \overline{r e t}_{c}+\delta_{2} X_{c}+\varepsilon_{c}
$$

where $X_{c}$ is a set of factors affecting the second term in (2). Indeed, if occupational employment shares were exogenous, our approach would identify the causal effect of occupations on a country's average retirement age. As we have pointed out in the introduction, however, Social Security legislation can shape a country's comparative advantage and impact occupational distribution through international specialization. Also, the occupational distribution can reversely impact Social Security programs through 
the median voter. In either case, the weights $w_{c, o}$ are not entirely independent of other factors influencing a country's average retirement age. We are therefore careful to read our results as a variance decomposition only.

Implementing our approach we proceed with the following two steps. In a first step, we compute the average retirement age per occupation. In a second step, we employ the estimates from the first step to predict the retirement age for a given country $c$ according to (4).

Finally, we take our prediction, $\overline{r e t}_{c}$ from equation (4) and assess to what extent it explains differences in the effective age of retirement across countries. We do so in two different ways. First, based on equation (3), we calculate the share of variation in the effective retirement age that is explained by the variation in the first term of its right hand side. Second, we regress the effective retirement age on $\overline{r e t}_{c}$ according to (5) and estimate the goodness of fit through the $R^{2}$.

\subsection{The Age of Retirement at the Occupational Level}

We begin by calculating ret $_{o}$, a clean measure of the average retirement age for each occupation. We use individual employment data and estimate the simple empirical model

$$
\text { ret }_{i}=\sum_{o} \beta_{o} D_{o}+\gamma Z_{i}+\varepsilon_{i}
$$

where $r e t_{i}$ is the retirement age and the indices $o$ and $i$ indicate the occupations and individuals, respectively. $D_{o}$ stand for occupation dummies and $Z_{i}$ is a vector of control variables that are likely to impact an individual's retirement age. The error term $\varepsilon_{i}$ is assumed to be normally distributed. Henceforth, we refer to this first step as the first stage. Since the U.S. has a relatively lean Social Security and welfare system, we estimate this first stage with data from the U.S. This could be an acceptable approximation of our hypothetical undistorted economy through which we want to define ret $_{o}$. Moreover, it is important to note that deviations from the occupational retirement age of the hypothetical undistorted economy are likely to limit our ability to explain cross-country differences in the retirement age. Thus, our results should be taken as a lower bound of 
the importance of occupations in explaining cross-country differences in the retirement age.

\subsubsection{Estimating the Occupational Retirement Age}

To estimate equation (6), we use IPUMS-CPS employment data provided by the U.S. Census Bureau. We limit the data to the years from 1990 to 2010 to obtain enough observations and at the same time span a period that is comparable in terms of Social Security, technologies and retirement patterns. ${ }^{16}$

Following the previous literature, we focus on male individuals. To identify retiring men, we assume that a worker retires when, simultaneously, he is aged 50 or above, reports to be "not in labor force" (according to the variable Employment Status) and reported working 45 weeks or more in the previous year (according to Weeks Worked Last Year). These restrictions leave us with 4,989 observations, each corresponding to the retiring incident of one individual. The IPUMS-CPS provides us with the variable Occupation Last Year, which reports the person's primary occupation during the previous calendar year. Accordingly, we could identify the last occupation of retirees. However, the occupational coding scheme for the CPS changed over time. We thus use the variable 'occupation last year, 1950 basis', which is time-invariant. Finally, the ample information of the individual CPS data allow us to include dummies for the 179 relevant classes of occupations, but also to control for education level, marital status, year and state effects when estimating equation (6). ${ }^{17}$

With the retirement incidents thus identified and using the information provided by control variables, we can estimate equation (6) at the individual level. The four columns

\footnotetext{
${ }^{16}$ Hazan (2009) documents that labor force participation of white American males above age 45 has been monotonically declining across cohorts born between 1840 and 1930. However, using data spanning from 1992 through 2000, Coile and Gruber (2007) find no significant time pattern to retirement behavior in the U.S. Interestingly, Quinn (1999) shows that the strong time series trend toward earlier retirement was arrested since the mid-1980s. Our calculations verify these previous findings and show that there is no time trend during the period: 1990-2010.

${ }^{17}$ Categories for 'Marital Status' are: Married, spouse present, Married, spouse absent, Separated, Divorced, Widowed, Never married/single. Categories for 'Education' are: No school completed; $1^{\text {st }}-4^{\text {th }}$ grade; $5^{\text {th }}-8^{\text {th }}$ grade; $9^{\text {th }}$ grade; $10^{\text {th }}$ grade; $11^{\text {th }}$ grade; $12^{\text {th }}$ grade; no diploma; High school graduate or GED; Some college, No degree; Associate degree, Occupational program; Associate degree, academic program; Bachelors degree; Masters degree; Professional degree; Doctorate degree.
} 
of Table 1 summarize the results of the underlying regression. In Column I we calculate a crude measure of the average retirement age for each occupation by running the first stage (6) without any control. However, the age of retirement is affected by other factors such as education, marital status among other things. Therefore, we would like to clean our measure from the impact of this type of information. We thus run three additional regressions. In the second regression, we control for a state-fixed effect. In the third one, we also add year dummies and in the fourth regression we add dummies for education and marital status. Thus, Table 1 summarizes the results for the first stage (6), for which we do not report the coefficients of all of the dummies but report the specification of the model, the number of observations and the adjusted $R^{2}$. The $R^{2}$ ranges between ten and twenty percent for the 4,500 to 5,000 individual observations. The lower part of the table shows the values of an F-test of the hypothesis that the coefficients on all of the occupation dummies $D_{o}$ are jointly zero. The according values range around three. In all specifications, the hypothesis that the coefficients of the $D_{o}$ are jointly zero is rejected on all conventional significance levels, indicated by the p-values.

Table A1 reports the full list of occupation classes together with the corresponding estimated retirement ages. It shows that within the upper end of the distribution, the estimated ages of retirement are 71, 67.2 and 66.6 for Psychologists (code 82), Architects (code 3) and Bookkeepers (code 310), respectively. Within the lower end of the distribution, the ages of retirement are 58.8, 60.2 and 61.6 for Automobile mechanics and repairmen (code 550), Airplane pilots and navigators (code 2) and Carpenters (code 510), respectively. ${ }^{18}$

\subsection{Predicting Cross-Country Retirement Ages}

In our second step, we employ the estimated coefficients $\hat{\beta}_{o}$ from the first stage (6) to predict the retirement age for a given country $c$ according to (4). Specifically, we compute

$$
\widehat{r e t}_{c}=\sum_{o} w_{c, o} \hat{\beta}_{o}
$$

\footnotetext{
${ }^{18}$ Some of estimated retirement ages are not very realistic - e.g., Optometrists (code 70) retire at age 80, Demonstrators (code 420) retire at age 78.9 and Bookbinders (code 502) retire at age 79. Such outliers results from the fact that the number of observations is very small for some of the occupations reported in Table A1. As explained below, however, the CPS occupations will be reclassified into broader classifications. Since we weight by occupation size in this process, the outliers are given very little weight, which substantially alleviates the problem (see Table A3 in the Appendix).
} 
Here, we weight by the employment shares $w_{c, o}$ of occupation $o$ in country $c$. Henceforth, we refer to the outcome of the expression (7) as our raw predictor. While the regression in the first step may include a series of control variables, the prediction in the second step relies only on the coefficients of the occupation dummies. Notice that $\widehat{r e t}_{c}$ is defined in parallel to $\overline{r e t}_{c}$ from equation (4) with the difference that ret $t_{o}$ are replaced by their

estimates, $\hat{\beta}_{o}$, we account for this difference by this slightly different notation. Thus, equation (5) is being modified to

$$
\operatorname{ret}_{c}=\rho_{1} \widehat{r e t}_{c}+\rho_{2} X_{c}+\pi_{c}
$$

\subsubsection{Comparing Occupational Retirement Ages Across Countries}

When constructing the raw predictor, (7), a central underlying assumption is that the distribution of occupational retirement ages is similar across countries. Indeed, our presumption is that the age of retirement is occupation-specific and stems from the intrinsic characteristics of each occupation, such as physical requirement or the pace at which job-specific knowledge depreciates. We do not blindly accept this assumption but ask whether individuals within the same occupation in different countries retire at similar ages. To answer this question we use the Survey of Health, Ageing and Retirement in Europe (SHARE), which provides data on retirement by occupation for 12 European countries. ${ }^{19}$ Using information for 5355 European retirees from this source we can estimate the average age of retirement for the 25 occupation classifications. ${ }^{20}$ Figure 4 plots

\footnotetext{
${ }^{19}$ The SHARE is a multidisciplinary and cross-national panel database of micro data on health, socioeconomic status and social and family networks of more than 55,000 individuals from 20 European countries aged 50 or over. We use Wave 1, for which data on occupation are available for 12 countries. These countries are Austria, Germany, Sweden, Netherlands, Spain, Italy, France, Denmark, Greece, Switzerland, Belgium and Israel. Henceforth, we will refer to these twelve countries as Europe. For a complete description of SHARE, see the dedicated website: www.share-project.org. The SHARE data collection has been primarily funded by the European Commission through the 5th framework programme (project QLK6-CT-2001-00360 in the thematic programme Quality of Life). Additional funding came from the US National Institute on Aging (U01 AG09740-13S2, P01 AG005842, P01 AG08291, P30 AG12815, Y1AG-4553-01 and OGHA 04-064). Data collection in Austria (through the Austrian Science Fund, FWF), Belgium (through the Belgian Science Policy Office) and Switzerland (through BBW/OFES/UFES) was nationally funded.

${ }^{20}$ In both data sources we have 43 different ISCO- 88 classification at a two-digit level. However, these two different classifications do not completely coincide so that we need to merge some of the classifications. This leaves us with 25 broader classification
} 
the occupational averages for the U.S. and Europe, illustrating a positive correlation of $68 \%$.

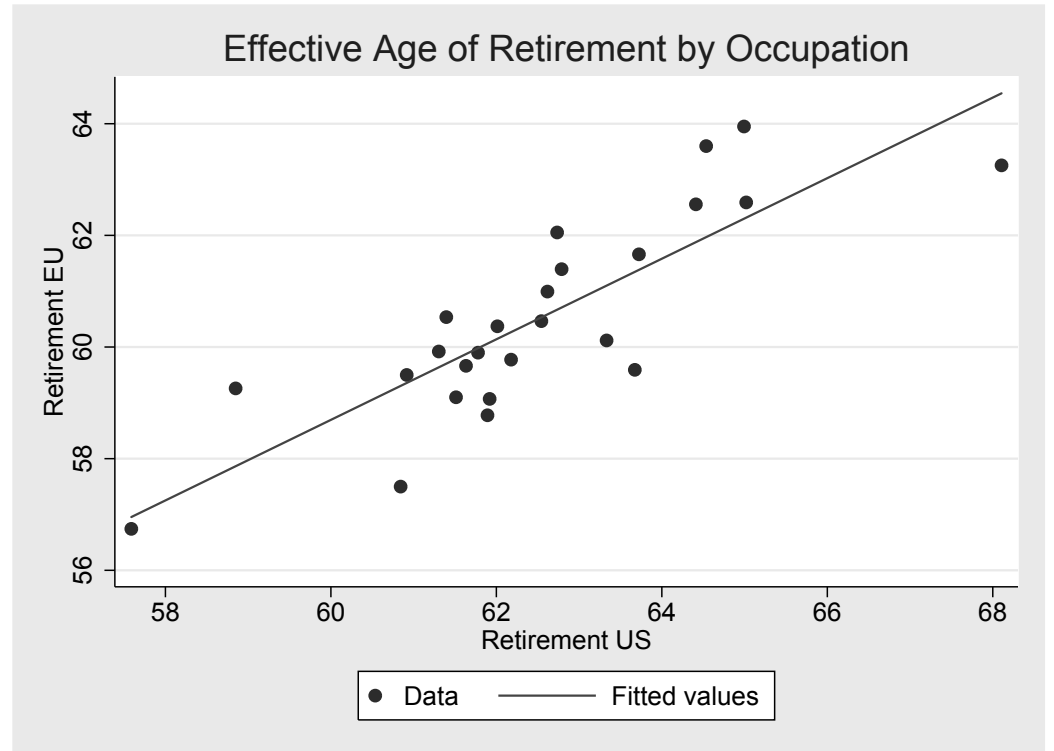

Figure 4: The average age of retirement in the U.S. versus Europe across 25 2-digit ISCO- 88 occupations.

Of course, the occupational age of retirement is affected by other factors such as Social security and welfare programs that differ across countries. Therefore, it may be the case that farmers and factory workers in the U.S. do not retire exactly at the same age as farmers and factory workers in Germany but their relative retirement age or ranking is preserved. To address this question we examine the similarity in the ranking of occupational retirement age across countries. We calculate the Spearman rank correlation between the US and the European occupational average, which is $76 \%$.

Motivated by the strong similarity of occupational retirement ages across countries, we proceed by estimating the age of retirement at the occupational level from the U.S. data to predict the average retirement age for the rest of the world.

\subsection{Predictions for OECD Countries}

Could U.S. occupational data explain differences in the effective age of retirement across countries? We are now ready to answer this central question of the current paper. To this 
end, we use our estimates from the first stage (6) for the retirement ages by occupation in the U.S. to predict the ages of retirement over a set of countries. To use the pure information revealed by the differences in occupations, we control in the first stage (6) for years, state effects, marital status and level of education (see Table 1, Column IV). The estimated occupational retirement ages are those from the previous subsection (Table A1).

An assessment of our raw predictor (7) requires a comparison with the effective, observed age of retirement for a set of countries. Such data is available for a broad set of OECD countries. ${ }^{21}$ Two additional virtues arise from focusing on the OECD countries. First, this set of countries is relatively homogenous and second, the quality of OECD data is generally high. ${ }^{22}$

We need to know the occupational employment shares $w_{c, o}$ in order to actually compute the raw predictor (7) for different countries. To construct this variable, we use ILO data, which provides the number of working individuals by gender, disaggregated according to different classification systems of occupations for 85 counties. For a subset of 42 of these countries, occupational data are reported based on the ISCO-88 classification. We use this subsample of countries for our exercise. ${ }^{23}$

Finally, we obviously need to know the estimated age of retirement of each occupation to compute our raw predictor (7). Unfortunately, the estimates that we calculated in the first stage using U.S. data according to (6) are not directly comparable to the ILO data since the former are coded using the 1950 census classification scheme while the latter are based on ISCO-88 classification. Therefore, we define a concordance table between the 1950 census classification scheme and the ISCO-88. ${ }^{24}$ With this concordance table we map 179 different occupations of the 3-digit 1950 census classification scheme to 43 categories of the 2-digit ISCO-88 classification scheme. When translating the estimated

\footnotetext{
${ }^{21}$ See (Table A4, Column III) of the Appendix.

${ }^{22} \mathrm{OECD}$ estimates are based on the results of national labor force surveys and the European Union Labor Force Survey. The OECD computes the average effective age of retirement "as a weighted average of (net) withdrawals from the labor market at different ages over a 5-year period for workers initially aged 40 and over. In order to abstract from compositional effects in the age structure of the population, labor force withdrawals are estimated based on changes in labor force participation rates rather than labor force levels. These changes are calculated for each (synthetic) cohort divided into 5-year age groups."

${ }^{23}$ For the list of countries see (Table A4, Column I) of the Appendix.

${ }^{24}$ see Table A2 of the Appendix
} 
coefficients on the occupation dummies obtained from the first stage regression (6) to the ISCO-88 classification, we note that more than one census classification code was assigned to some ISCO-88 codes. For these ISCO- 88 codes, we weight occupational retirement ages by the corresponding U.S. employment shares.

Table A3 of the Appendix reports the resulting constructed average retirement age for the 43 ISCO-88 occupations. The distribution of the estimated occupational retirement ages is now much more concentrated than in Table A1 and outliers in the upper and lower spectrum are less frequent.

Using the employment shares of the ISCO-88 occupations as weights, we can now easily compute the raw predictor according to equation (7). Recall that the occupational retirement ages, $\hat{\beta}_{o}$ in (7), are based on U.S. data but the weights $\left(w_{c, o}\right)$ are provided by the ILO.

Merging the data on the effective age of retirement provided by the OECD with our predicted age of retirement leaves us with 28 advanced countries (excluding U.S.). We restrict our cross-country analysis to the year 2000, which leaves our set of countries unchanged. ${ }^{25}$

To assess the success of our raw predictor, $\widehat{r e t}_{c}$ from (7) we decompose the variance in the effective age of retirement and compute the share of the variance in the cross-country retirement ages that is explained by our predictions, i.e. we compute

$$
1-V A R\left(r_{e} t_{c}-\widehat{r e t}_{c}\right) / V A R\left(r e t_{c}\right)
$$

The expression computed in (9) equals one when the raw predictor perfectly fits the effective data and negative (and potentially unbounded) in case our raw predictor is independent or negatively correlated with the effective data.

With this variance decomposition we evaluate the success of our raw predictor by computing the part of the variance explained by our prediction. According to this exercise, our prediction explains $10.3 \%$ of the cross-country variation. Thus, the U.S. occupational retirement ages can explain about a tenth of the considerable cross-country vari-

\footnotetext{
${ }^{25}$ Our restriction eliminates one data points for Cyprus, South Korea, Poland Portugal and Switzerland, respectively.
} 
ation in average retirement age merely through the occupational composition effects of the different countries.

For each individual country, we further compute the deviation from the 'naturally implied' retirement age by considering the differences between the effective retirement age, ret $_{c}$, and the predicted one, $\widehat{r e t}_{c}$.

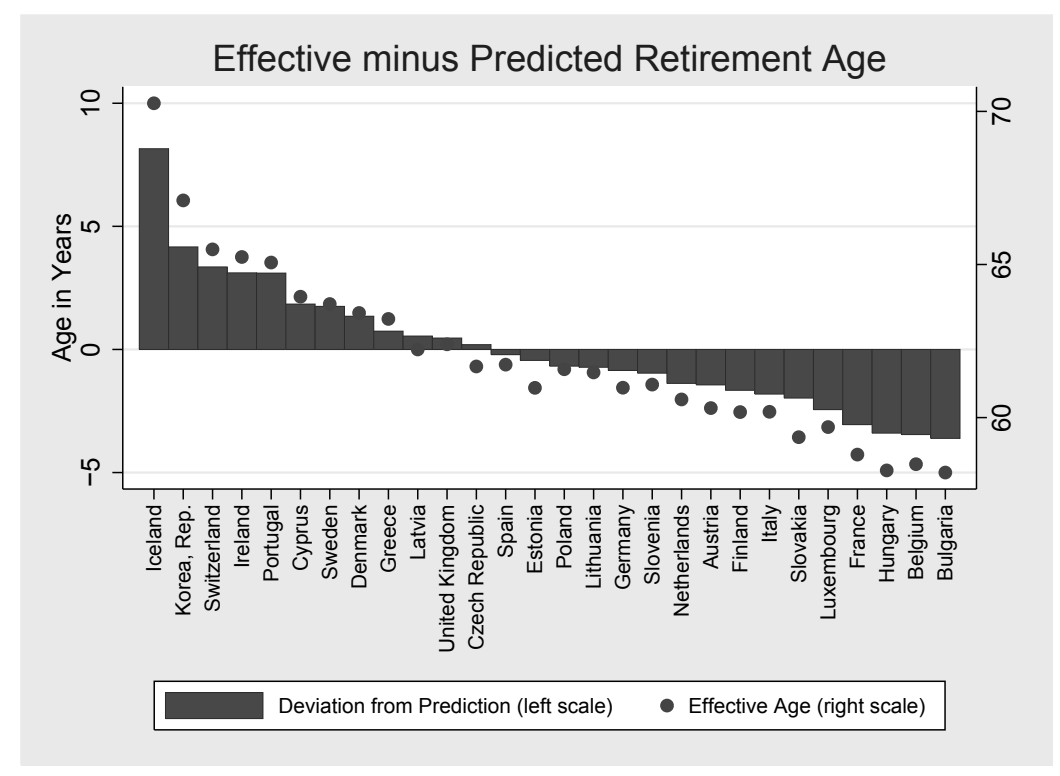

Figure 5: The bars are the effective minus predicted age of retirement (left scale) and the red dots are the effective age of retirement (right scale) for the year 2000. Source: Authors' calculations based on data from OECD, ILO, and CPS.

Figure 5 plots these deviations. While male workers in Iceland, South Korea and Switzerland retire relatively late, those in Hungary, Belgium and Bulgaria retire much earlier than their occupational distribution would suggest. Interestingly, the average effective retirement age of males in Spain is almost exactly the same as in the U.S. when accounting for the occupational distribution. Another interesting example are Czech Republic and Poland with virtually identical effective retirement ages; but Czechs retire nearly ten months later when correcting for the respective occupational composition. Conversely, the observed difference of 27 month in the retirement age between Greece (age 63.22) and Germany (age 60.98) shrinks to less than twenty months when accounting for occupations. Nevertheless, the effective retirement age in Greece is more than a year higher than is predicted by its occupational distribution (+1.21), while Germany falls short of 
the prediction by about half a year (-0.43). Quite generally, those countries that have frequently faced requests to reform and tighten their pension systems during the current Euro Crisis (Portugal, Greece, Spain) see positive and higher deviations from the predictions than countries from which such requests originate (Germany, France) ${ }^{26}$

\subsubsection{Refining the Prediction of Retirement Age}

The variance decomposition (9) has shown that the predicted age of retirement explains more than ten percent of the variation in the effective age of retirement. However, our prediction can be even further improved by accounting for the fact that the link between occupations and the age of retirement may differ across countries. For example, Social Security and welfare programs may magnify the differences in the retirement ages across occupations. Clearly, the U.S. has a relatively lean Social Security system compared to most other OECD countries, which may compress the occupational distribution of retirement ages in the U.S. Moreover, the inevitable loss of information in the crosswalk of occupation classifications defined in Table A2 are likely to blur the differences in the according retirement ages and compress the distribution of retirement ages. Both effects mentioned may imply that one year's difference in our raw predictor of retirement age actually reflect a much larger difference in effective retirement ages.

To correct for these influences in a very rough way, we refine our predictor through a linear transformation. Specifically, we run several regressions according to (8) and estimate the coefficient, $\rho_{1}$, by which our raw predictor impacts the effective age of retirement. In these regressions we can, at the same time, control for Social Security variables and other relevant factors.

Figure 6 plots the effective against the predicted retirement age for the 28 countries. While the two variables exhibit a strong and clearly positive correlation, it is striking that the slope of the included trend line exceeds one. ${ }^{27}$ Table 2, Column I reports the results of the corresponding regression, showing that the estimated coefficient, which is significant at the one percent level, is 4.7 . This means that a one year increase in the raw

\footnotetext{
${ }^{26}$ Italy might be regarded as an exception to this rule.

${ }^{27}$ Notice that the deviations from the trend line do not correspond to those plotted in Figure 5, where deviations from the $45^{\circ}$ line are measured.
} 


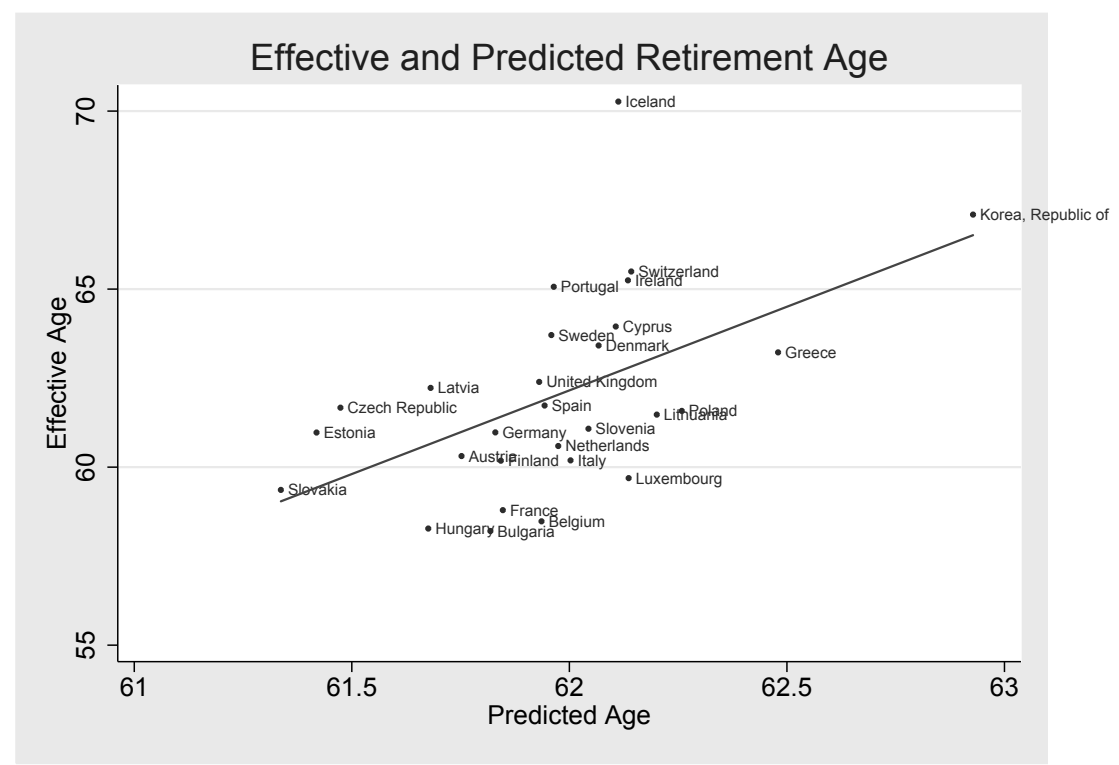

Figure 6: The effective vs. predicted age of retirement across 28 OECD countries for the year 2000.

predictor is associated with 4.7 years increase in the effective retirement age. Finally, the adjusted $R^{2}$ is 0.28 , which implies that our raw predictor can explain more than a quarter of the cross-country variation of retirement ages within a sample of 28 OECD countries.

Interestingly, the fact that the estimated coefficient on our raw predictor exceeds one is consistent with both suggestions from above - the compression of our predictor due to either Social Security systems or else due to the translation of occupation codes in the crosswalk. While both effects obviously steepen the slope in Figure 6 and lead to a higher estimated coefficient, the former explanation is reminiscent of the explanation that Ljungqvist and Sargent (1998) provide for the long-term unemployment in welfare states during the 1980s. Specifically, the authors argue that without technological progress unemployed workers easily get back into employment even with a generous unemployment benefits. However, in periods of fast technological progress the skill of laid-off workers quickly becomes obsolete and generous unemployment compensations prevent them from accepting new job offers. Analogously, workers in occupations characterized by high levels of human capital depreciation might retire early when the Social Security and welfare programs are relatively generous and retire late otherwise. 
Whereas, the age of retirement of workers in the other occupations might be less dependent on the generosity of the Social Security and welfare programs.

The observation that an economy's Social Security system appears to influence our predicted retirement age might actually be a source of potential concern. Specifically, Social Security legislation might be the overriding determinant of all direct and indirect effects on retirement age, which, once it is accounted for, leaves no room for other explanations. To address such concerns, we now turn to an econometric model, as specified in equation (8) and controls for institutional determinants of the average effective retirement age.

\subsubsection{Occupational Distribution vs. Institutional Factors}

Our approach to explain a country's effective retirement ages by its occupational composition faces a broad literature that stresses the individual's incentives in explaining the cross-country differences in retirement ages.

To give a first assessment of the relative importance of these two approaches, we include both, political variables and our raw predictor, to explain the variation of effective retirement ages in our OECD sample. Specifically, we use data about Social Security systems from the U.S. Social Security Administration's "Social Security Programs Throughout the World" as reported in Bloom et al. (2009). Five categories of interest are presented there, the first three of which are Eligibility (age of entitlement to full Social Security benefits), Allowed (number of years before the eligibility age during which early retirement -at reduced benefits- is allowed), and Deferred Bonus (increase in benefits due to an additional year of work past the eligibility age). The last two measures that are Replacement Benefit and Replacement Contribution capture the share of average earnings replaced by the pension if the worker retires at the normal eligibility age. ${ }^{28}$

For the year 2000, these variables are available for 40 countries. ${ }^{29}$ Merging the data with our OECD dataset leaves us with 17 observations. We run regressions of the effective retirement age on the raw predictor and find that within this group of homogenous

\footnotetext{
${ }^{28} \mathrm{As}$ in Bloom et al. (2009), replacement rate from the defined benefit portion of a scheme is measured separately from the one that accrues from defined contributions.

${ }^{29}$ See Table A4, Column IV of the Appendix.
} 
countries the coefficient on the raw predictor is significant at the one percent level; the $R^{2}$ is 0.47 (see Table 2 Column II). We add each one of the five policy variables separately and find that the significance of our predicted age of retirement is intact (Table 2 Columns III-VII). Next, we run the effective age of retirement on these five policy variables jointly, excluding and including our raw predictor (Table 2 Columns VIII and IX). The $R^{2}$ is 0.44 and 0.84 , respectively. In the last specification our raw predictor is still significant at the one percent level.

While we are mainly interested in the performance of our raw predictor, it is reassuring to note that, overall, the social security variables explain a good share of the crosscountry variation in retirement age. In line with the findings from Bloom et al. (2009), Table 2 shows that fewer allowed years of early retirement, higher replacement rate in the defined benefit scheme and lower replacement rate in the defined contribution scheme are positively associated with a higher retirement age. Table 2 also shows the social security eligibility ages and the bonus for deferring retirement are not significantly correlated with the retirement age. This lack of significance may be the result of limited variation these two variables exhibit within our set of countries. Nevertheless, the coefficients of these two variables still have the expected positive sign.

We further extend the variables Eligibility and Allowance to our set of OECD countries by going back to the database "Social Security Programs Throughout the World" from the U.S. Social Security Administration, which Bloom et al. (2009) use for their calculations. ${ }^{30}$ Specifically, we complete the variables Eligibility and Allowance for all countries in our original set of countries, using data for the year 1999. Columns X and XI report the corresponding regression results. Neither of the control variables, Eligibility and Allowed, is significant in this extended set of countries. ${ }^{31}$ Most importantly, however, the estimates of the coefficient of interest remain significant with virtually unchanged

\footnotetext{
${ }^{30}$ Our source is the International Social Security Association, which provides detailed descriptions of Social Security programs. These descriptions comprise all information of the publication "Social Security Programs Throughout the World" of the U.S. Social Security Administration, referred to by Bloom et al. (2009). The International Social Security Association reports early retirement for five countries (Czech Republic, Ecuador, Iceland, Lithuania and Hungary). We set this variable to zero for those countries in the database for which it is not specifically reported. Three additional variables exist: Deferred Bonus and the two measures of replacement rate. Bloom et al (2009) compute these variables based on the definition of a representative worker and formulas that are not further specified. We do not extend these variables to our set of countries.

${ }^{31}$ This lack of significance may indicate that the variables are less reliable than for the limited sample.
} 
magnitudes.

\subsection{Predicting Retirement Age for an Extended Sample}

We next extend the range of countries for which we compare the effective with the predicted retirement age. Consistent data on employment by occupation is relatively hard to obtain and the ILO data of occupational distribution already provides a good coverage of countries. We thus enlarge our sample by extending the set of countries for which we can obtain effective average retirement age. Specifically, we use ILO data on employment by age group to compute a proxy for the effective retirement age, relying on the method employed by the OECD (see Footnote 22). Hence, we compute for country $c$ the employment shares $\theta_{c, a}$ for each five-year age group $a$ starting from age 40 . We then calculate

$$
\text { ret }_{c}=\sum_{a}\left(\theta_{c, a}-\theta_{c, a-1}\right) \cdot a
$$

where $a$ runs over all age groups and $\theta_{c, a} \equiv 1$ if $a<40$.

With this method, we proxy the countries' retirement ages. To keep our previous terminology and considering that our calculation method relies on that of the OECD, we refer to these proxies as effective retirement ages. Our calculations increase the set of countries for which we have raw predictor and effective retirement ages to 38 countries. ${ }^{32}$ For most of these countries, data exist in the year 2000. For the few exceptions, we take the closest available year to $2000 .{ }^{33}$ In the following, we will refer to this set of countries as the "full sample".

Figure 7 shows that, within the sample of countries for which OECD data and our own calculations exist, a strong correlation exists between the two proxies of effective average retirement age. With the exception of Mexico, all countries lie reasonably close to the 45degree line in the scatterplot. In a regression, the estimated coefficient is 1.4 , with a standard deviation 103 and an adjusted $R^{2}$ of 0.832 (when excluding Mexico the figures are $1.261,0.084$ and 0.86 respectively).

\footnotetext{
${ }^{32}$ See (Table A4, Column III) of the Appendix.

${ }^{33}$ These exceptions are Uganda 1991; Gabon 1993, Iran 1996, Seychelles 1997, Pakistan 1998, and Hong Kong 2001.
} 


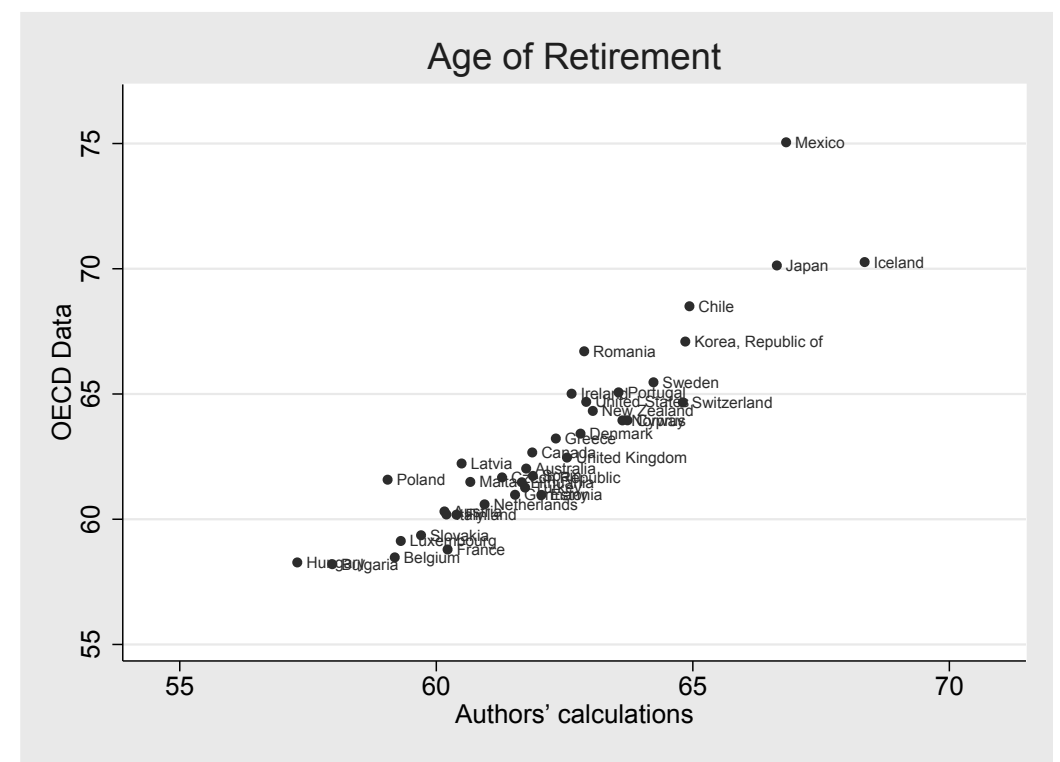

Figure 7: The effective age of retirement - OECD vs. authors' calculations - based on ILO data.

A variance decomposition according to equation (9) shows that our raw predictor explains $17 \%$ of the cross-country variance in the age of retirement. This result constitutes a substantial improvement over the previous predictions based on the advanced countries only.

Figure 8 provides a graphical representation of the fit, plotting the effective versus the predicted retirement age for our full sample (replicating the impressive correlation of Figure 6). It is especially striking that our predictions, which are based on U.S. employment data, perform well for very diverse and less developed countries such as Uganda, Pakistan, Gabon and Iran.

Table 3, Column I reports the regression results corresponding to the trend line in Figure 8. The coefficient of interest is now 3.8 and significant at the one percent level. This implies that a one year increase in our raw predictor increases the age of retirement by 3.8 years. The $R^{2}$ of this specification is 0.39 . Thus, following our earlier interpretation, our refined predictor explains close to $40 \%$ of the cross-country variation in the average effective retirement age. Since this full sample includes some observation of years different from the year 2000, our baseline specification, which is reported in Column II, includes the year of observations to control for global trends in the retirement age. In 


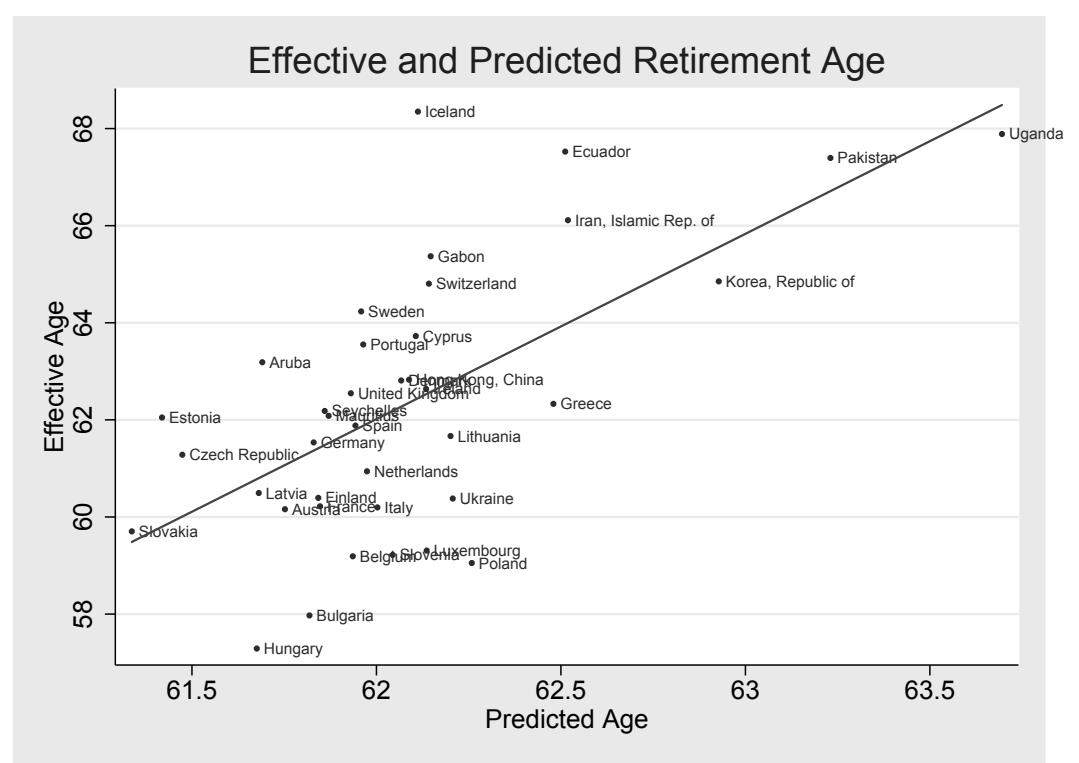

Figure 8: The effective vs. predicted age of retirement across 38 countries for the year 2000 for most countries and for some countries the closest available year to 2000.

this baseline specification the estimated coefficient on the raw predictor declines to 3.2 The adjusted $R^{2}$ improves relative to the OECD sample and stands at 0.42 .

In this full sample, we repeat our previous exercise by including the five political variables that capture Social Security and pension incentives, discussed in the previous section, in order to test whether our variable of interest - the raw predictor - survives the inclusion of these variables in a very heterogenous sample that includes not only developed countries but also developing ones. Columns IV-XII of Table 3 show the corresponding specifications of Columns III-XI of Table 2. Overall, our conclusions drawn from the OECD sample with regard to the inclusion of the political variables are repeated in the full sample.

A noticeable difference between the two samples, however, is the magnitude of the coefficient on the raw predictor. In the OECD sample, its magnitude ranges around 6.5, while in the enlarged sample its magnitude ranges around 3.5. Thus, the inclusion of developing countries reduces the magnitude of our coefficient. This observation supports our conjecture from before that the magnitude of our coefficient is affected, among other things, by the welfare economy. While OECD (mainly European) countries provide much more generous financial support than most emerging countries, retirement 
decisions of individuals in the latter countries are less sensitive to their occupations as old age consumption needs to be financed by a longer work life.

\subsection{Robustness}

For a last robustness check, we also include the control variables GDP Per Capita (in US dollars, logged), Urban Population (in percent of population) and Life Expectancy (at birth, in years for male population). These three variables are readily available in the World Development Indicators (WDI), provided by the World Bank. A fourth variable Average Schooling is from Barro and Lee (2000). ${ }^{34}$

Table 4 reports the regression results when including these control variables, jointly or separately, in our full sample. In the baseline specification within this full sample we control for year trend just as in the regressions reported in Table 3 (see footnote 33). Clearly, Table 4 shows that controlling for all four variables affects neither the significance nor the magnitude of our predicted age of retirement. The coefficient is around 3.5 and significant at the one percent level. The control Life Expectancy included in Column II is the only one that is significant, although only marginally so. Also, the adjusted $R^{2}$ increases somewhat compared to the regression excluding all controls (Table 3, Column III).

Finally, to make sure that our results are not driven by exception of the armed forces, we exclude this occupation from our forecasts and estimations and find that all of our results are virtually unchanged.

\section{Conclusion}

Economic literature has studied retirement decisions mainly from the viewpoint of institutional incentives and consequently linked cross-country differences to Social Security

\footnotetext{
${ }^{34}$ Data on Average Schooling are missing for Aruba, Gabon, Luxembourg and Ukraine.
} 
and pension systems. In this paper, we have proposed a new perspective on the crosscountry differences in the age of retirement. We have looked at the occupational composition and its link to the effective average age of retirement. Our explanation leans on two prerequisites. First, the age of retirement is occupation-specific and stems from the intrinsic characteristics of each occupation, such as physical requirements or the pace at which job-specific knowledge depreciates. Second, occupational distribution varies significantly across countries. We use the rich U.S. data to infer a proxy for the average retirement age by occupation, thereby controlling for state dummies, marital status, the level of education and year dummies. Based on the resulting measure of retirement age, we construct a raw predictor of average retirement age by weighting the occupational retirement age with occupational employment shares. Our predictor, which is based on U.S. data, explains up to $39.2 \%$ of the cross-country variation in the average effective retirement age for a sample of 38 countries. We also include in our analysis financial retirement incentives that the literature typically focuses on. In a regression of the effective average retirement age on our raw predictor plus relevant control variables 83\% of the observed sample variation are explained, while the coefficient on our predicted age of retirement is significant at the one percent level. The general picture does not change when we include per-capita GDP, life expectancy, the share of urban population and average schooling in the regression. These results indicate that there is a strong link between countries' occupational distribution and the age of retirement, even controlling for variables that typically explain retirement ages. For each country, our raw predictor of retirement age also constitutes an interesting 'natural benchmark' against which we can compare the effective retirement ages. This comparison delivers noteworthy insights. Thus, the Czech Republic and Poland have virtually identical effective retirement ages, but Czechs retire almost ten months later when correcting for the respective occupational composition. Conversely, the observed difference of 27 month in the retirement age between Greece (age 63.2) and Germany (age 61.0) shrinks to less than 20 month when occupations are accounted for.

Finally, by highlighting the strong link between a country's average retirement age and its occupational distribution our findings may stimulate research about the extent to which life-cycle savings are affected by occupational structure. The subsequent impli- 
cations for the current account and sustainability of pension systems might be worth studying as well. In this realm, the role of economic development or international specialization as underlying determinants of occupational structure might be especially interesting.

\section{References}

Acemoglu, Daron and David Autor, "Skills, Tasks and Technologies: Implications for Employment and Earnings," in "Handbook of Labor Economics," Vol. 4b, Elsevier B.V., 2011, pp. 1043-1171.

Ahituv, Avner and Joseph Zeira, "Technical Progress and Early Retirement," 2000. Unpublished Manuscript, the Hebrew University.

Allen, Steven G., "Technology and the Wage Structure," Journal of Labor Economics, 2001, $19(2), 440-483$.

Amiti, Mary and Shang-Jin Wei, "Service Offshoring and Productivity: Evidence from the US," The World Economy, 2009, 32 (2), 203-220.

Aubert, Patrick, Eve Caroli, and Muriel Roger, "New Technologies, Organisation and Age: Frim-Level Evidence," Economic Journal, February 2006, 116, F73F93.

Autor, David and David Dorn, "The Skill Content of Jobs and the Evolution of the Wage Struct ure," American Economic Review: Papers E Proceedings, 2009, 99 (2), 45-51.

Bartel, Ann P. and Frank R. Lichtenberg, "The Comparative Advantage of Educated Workers in Implementing New Technology," Review of Economics and Statistics, February 1987, 59, 1-11.

and Nachum Sicherman, "Technological Change and Retirement Decisions of Older Workers," Journal of Labor Economics, January 1993, 11 (1), 162-183. Part 1: Essays in Honor of Jacob Mincer. 
Bloom, David E., David Canning, Gnther Fink, and Jocelyn E. Finlay, "The Effect of Social Security Reform on Male Retirement in High and Middle Income Countries," November 2009. PGDA Working Paper No. 48.

Blundell, Richard, Costas Meghir, and Sarah Smith, "Pension Incentives and the Pattern of Early Retirement," The Economic Journal, March 2002, 112 (478), C153-C170. Conference Papers.

Burtless, Gary, "Social Security, Unanticipated Benefit Increases, and the Timing of Retirement," The Review of Economic Studies, October 1986, 53 (5), 781-805.

_ Work, health and income among the elderly, Washington, DC: Brookings Institution, 1987.

Coile, Courtney, "Retirement Incentives and Couples Retirement Decisions," Berkeley Electronic Press, 2004.

and Jonathan Gruber, "Social Security and Retirement," Review of Economics and Statistics, May 2007, 89 (2), 234-246.

Ebenstein, Avraham, Ann Harrison, Margaret McMillan, and Shannon Phillips, "Estimating the Impact of Trade and Offshoring on American Workers Using the Current Population Surveys," January 2011. Unpublished Manuscript.

Filer, Randall K. and Peter A. Petri, "A Job-Characteristics Theory of Retirement," Review of Economics and Statistics, 1988, 70 (1), 123-128.

Friedberg, L., "The impact of technological change on older workers: evidence from data on computer use," Industrial and Labor Relations Review, April 2003, 56 (3), 511529.

Galor, Oded, "The Demographic Transition and the Emergence of Sustained Economic Growth," Journal of the European Economic Association, May 2005, 3, 494-504.

and David N. Weil, "Population, Technology, and Growth: From Malthusian Stagnation to the Demographic Transition and Beyond," American Economic Review, September 2000, 90 (4), 806-828. 
Goos, Maarten, Alan Manning, and Anna Salomons, "Job Polarization in Europe," 2008. Unpublished.

Gruber, Jonathan and David A. Wise, Social Security and Retirement around the World., Chicago: The University of Chicago Press, 1999.

_ and _ Social Security Programs and Retirement around the World: MicroEstimation, Chicago: The University of Chicago Press, 2004.

_ _ and David Wise, "Social Security and Retirement: An International Comparison," The American Economic Review, Papers and Proceedings, May 1998, 88 (2), 158-163.

Gustman, Alan L. and Thomas L. Steinmeier, "The social security early entitlement age in a structural model of retirement and wealth," Journal of Public Economics, February 2005, 89 (2-3), 441-463.

Haveman, R ., B. Wolfe, and J. Warlick, "Behavioral Responses to Social Security Retrenchments: Etimates From a Trichotomous Choice Model," 1985. Discussion Paper 789-85 presented at the Institute for Research on Poverty University of Wiscon$\sin$.

Hayward, Mark D., “The Influence of Occupational Characteristics on Mens Early Retirement," Social Forces, 1986, 64 (4), 1032-45.

_ Melissa A. Hardy, and William R. Grady, "Labor Force Withdrawal Patterns among Older Men in the United States," Social Science Quarterly, June 1989, 70 (2), 425-448.

_ William R. Grady, Melissa A. Hardy, and David Sommers, "Occupational Influences on Retirement, Disability, and Death," Demography, August 1989, 26 (3), 393-409.

Hazan, Moshe, "Longevity and Lifetime Labor supply: Evidence and Implications," Econometrica, November 2009, 77, 1829-1863.

Hurd, Michael and Kathleen McGarry, "The Relationship between Jobs Characteristics and Retirement," December 1993. NBER, Working Paper No 4558. 
Imbs, Jean and Romain Wacziarg, "Stages of Diversification," American Economic Review, March 2003, 93 (1), 63-86.

Kalemli-Ozcan, Sebnem and David N. Weil, "Mortality Change, the Uncertainty Effect, and Retirement," Journal of Economic Growth, March 2010, 15 (1), 65-91.

Karpansalo, Minna, Pirjo Manninen, Timo A. Lakka, Jussi Kauhanen, Rainer Rauramaa, and Jukka T. Salonen, "Physical Workload and Risk of Early Retirement: Prospective Population-Based Study Among Middle-Aged Men," Journal of Occupational and Environmental Medicine, 2002, 44 (10), 930-939.

King, Miriam, Steven Ruggles, Trent J. Alexander, Sarah Flood, Katie Genadek, Matthew B. Schroeder, Brandon Trampe, and Rebecca Vick, Integrated Public Use Microdata Series, Current Population Survey: Version 3.0 [Machine-readable database]. Minneapolis: University of Minnesota 2010.

Krueger, Alan B. and Jörn-Steffen Pischke, "The Effect of Social Security on Labor Supply: A Cohort Analysis of the Notch Generation," Journal of Labor Economics, October 1992, 10 (4), 412-437.

Levinsohn, James, "Employment responses to international liberalization in Chile," Journal of International Economics, 1999, 47 (2), 321-344.

Liu, Runjuan and Daniel Trefler, "Much Ado About Nothing: American Jobs and the Rise of Service Outsourcing to China and India," 2008. NBER Working Paper No. 14061.

Ljungqvist, Lars and Thomas J. Sargent, “The European Unemployment Dilemma," Sargent, June 1998, 106 (3), Sargent.

Mincer, Jacob and Yoshio Higuchi, “Wage Structures and Labor Turnover in the United States and Japan," Journal of the Japanese and International Economies, 1988, 2, 97-133.

Mitchell, Olivia and Gary S. Fields, "The Economics of Retirement Behavior," Journal of Labor Economics, January 1984, 2, 84-105. 
Mitchell, Olivia S., Phillip B. Levine, and Silvana Pozzebon, "Retirement Differences by Industry and Occupation," The Cerontological Society of America, 1988, 28 (4), 545551.

Quinn, Joseph, "Retirement Patterns and Bridge Jobs in the 1990s," Policy Brief for the Employee Benefit Research Institute, 1999. Washington, DC: EBRI.

Quinn, Joseph F., "Microeconomic Determinants of Early Retirement: A Cross-sectional View of Married Men," Journal of Human Resources, 1977, 12 (3), 329-46.

_ _ "Job Characteristics and Early Retirement," Industrial Relations, October 1978, 17 (3), 315-323.

Revenga, Ana L., “Exporting Jobs?: The Impact of Import Competition on Employment and Wages in U.S. Manufacturing," The Quarterly Journal of Economics, February 1992, 107 (1), 255-284.

Rosen, Sherwin, "Measuring the Obsolescence of Knowledge," in F. T. Juster, ed., Education, Income, and Human Behavior, New-York: Carnegie Foundation and Columbia University Press, 1975, p. 199232.

Rust, John and Christopher Phelan, "How Social Security and Medicare affect retirement behavior in a world of incomplete markets," ECONOMETRICA, July 1997, 65 (4), 781-831.

Schott, Peter, "One Size Fits All? Heckscher-Ohlin Specialization in Global Production," American Economic Review, 2003, 93 (3), 686-708.

Schott, Peter K., "Across-Product versus Within-Product Specialization in International Trade," Quarterly Journal of Economics, May 2004, 119 (2), 647-678.

Stock, James H. and David A. Wise, "Pensions, the Option Value of Work, and Retirement," Econometrica, September 1990, 58 (5), 1151-1180. 
Table 1: Retirement Age Across U.S. States

\begin{tabular}{llll} 
I & II & III & IV \\
\hline
\end{tabular}

\begin{tabular}{lcccc}
\multicolumn{5}{l}{ Dep Variable: Retirement Age (Individual Level) } \\
\hline$D_{\text {occupation }}$ & yes & yes & yes & yes \\
$D_{\text {state }}$ & & yes & yes & yes \\
$D_{\text {year }}$ & & yes & yes \\
$D_{\text {marital }}$ & & & yes \\
$D_{\text {education }}$ & & & & yes \\
\hline Observations & 4972 & 4972 & 4972 & 4494 \\
R-squared & 0.105 & 0.119 & 0.124 & 0.205 \\
\hline Joint test $D_{\text {occ }}=0$ & & & & \\
F-statistic & 3.158 & 3.035 & 2.997 & 2.800 \\
p-value & 0.000 & 0.000 & 0.000 & 0.000 \\
& & & & \\
\hline
\end{tabular}

Note. - The table describes the resgression results of four different specifications of a the empirical model (1). Each specification corresponds to different sets of controls. Regressions are conducted on U.S. individual data from IPUMS-CPS. All models are weighted by CPS sampling weights. Control variables: (1) Doccupation comprises 179 dummies for occupations (3- digit census occupation scheme). (2) Dstate includes 50 U.S. states. (3) Dyear includes 21 dummies for the period 19902010. (4) Dmarital includes 6 dummies (see footnote 9 for categories). (5) Deducation includes 19 dummies (see footnote 9 for categories). Standard errors in parentheses. ${ }^{* * *} p<0.01,{ }^{* *} p<0.05, * p<0.1$. 


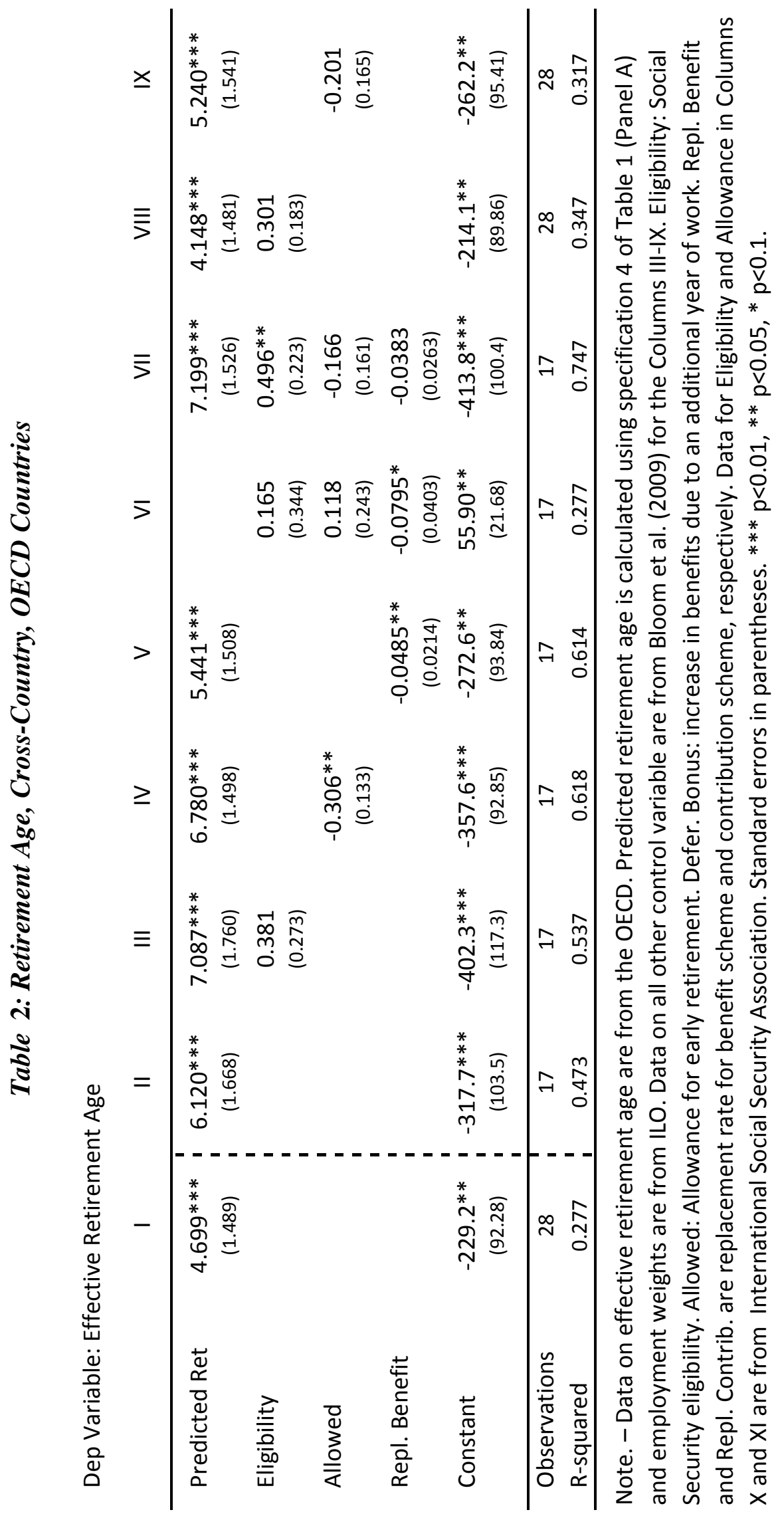




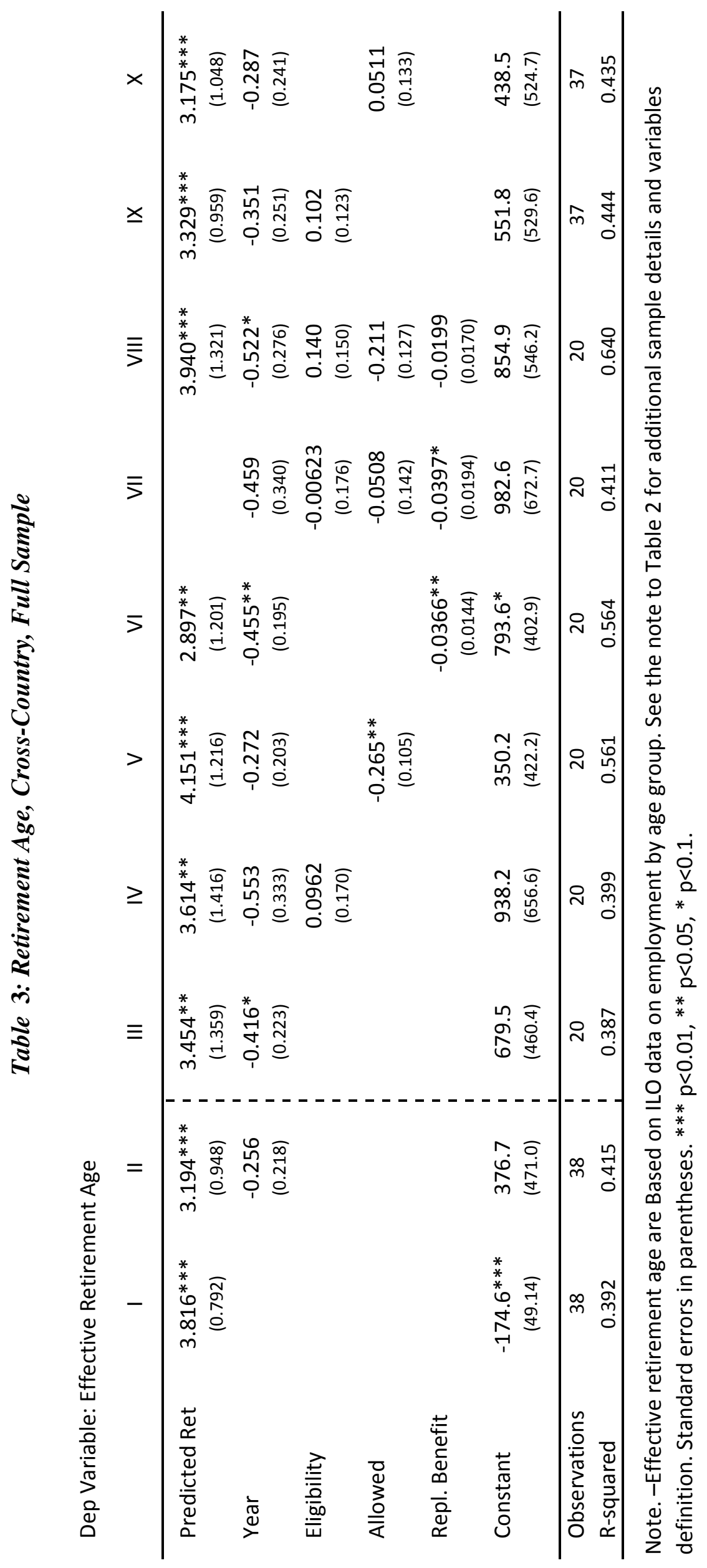


Table 4: Retirement Age, Socio-Economic Controls, Full Sample

Dep Variable: Effective Retirement Age

\begin{tabular}{lccccc} 
& $\mathrm{I}$ & $\mathrm{II}$ & $\mathrm{III}$ & $\mathrm{IV}$ & $\mathrm{V}$ \\
\hline Predicted Ret & $3.430^{* * *}$ & $3.221^{* * *}$ & $3.373^{* * *}$ & $3.725^{* * *}$ & $3.454^{* * *}$ \\
& $(0.978)$ & $(0.920)$ & $(0.969)$ & $(1.061)$ & $(1.082)$ \\
year & -0.341 & $-0.637^{* *}$ & -0.322 & 0.0561 & -0.423 \\
& $(0.234)$ & $(0.300)$ & $(0.229)$ & $(0.322)$ & $(0.472)$ \\
GDP p.c. & 0.331 & & & & -0.322 \\
& $(0.336)$ & & & & $(0.758)$ \\
Life Expect. & & $0.154^{*}$ & & & 0.153 \\
& & $(0.0860)$ & & & $(0.195)$ \\
Urban Pop. & & & 0.0223 & & 0.0440 \\
& & & $(0.0239)$ & & $(0.0379)$ \\
Av. Schooling & & & & -0.160 & -0.315 \\
& & & & $(0.240)$ & $(0.308)$ \\
Constant & 527.3 & $1124 *$ & 494.7 & -279.8 & 684.5 \\
& $(495.4)$ & $(619.0)$ & $(488.4)$ & $(676.0)$ & $(970.3)$ \\
\hline Observations & 38 & 38 & 38 & 34 & 34 \\
R-squared & 0.432 & 0.466 & 0.430 & 0.462 & 0.537 \\
\hline
\end{tabular}

Note. -Effective retirement age are Based on ILO data on employment by age group. Control variables: GDP per capita (in US dollars, logged), Urban population (in percent of population) and Life Expectancy (at birth, in years for male population) are from World Development Indicators (WDI), provided by the World Bank, Average Schooling is from Barro and Lee (2000). See the note to Table 2 for additional sample details and variables definition. Standard errors in parentheses. ${ }^{* * *} \mathrm{p}<0.01,{ }^{* *} \mathrm{p}<0.05,{ }^{*} \mathrm{p}<0.1$. 


\section{Appendix - For Online Publication}

Table A1: Census Occupational Classification Scheme (1950) and Retirement Age

\section{Occupation Description \\ Code}

0 Accountants and auditors

1 Actors and actresses

2 Airplane pilots and navigators

3 Architects

$4 \quad$ Artists and art teachers

5 Athletes

6 Authors

7 Chemists

9 Clergymen

18 Mathematics

27 Social sciences (n.e.c.)

28 Nonscientific subjects

29

31

32

33

35

36

41

42

43

44

45

46

48

49

51

53

54

55

56

57

58

61

62

62

68

69

70

72

73

74

75

76

78
Subject not specified

Dancers and dancing teachers

Dentists

Designers

Draftsmen

Editors and reporters

Engineers, aeronautical

Engineers, chemical

Engineers, civil

Engineers, electrical

Engineers, industrial

Engineers, mechanical

Engineers, mining

Engineers (n.e.c.)

Entertainers (n.e.c.)

Foresters and conservationists

Funeral directors and embalmers

Lawyers and judges

Librarians

Musicians and music teachers

Nurses, professional

Agricultural scientists

Biological scientists

Physicists

Miscellaneous natural scientists

Optometrists

Personnel and labor relations workers

Pharmacists

Photographers

Physicians and surgeons

Radio operators

Religious workers

\section{Retirement Age}

(Average)

62.6

71.0

60.2

67.2

67.0

67.0

61.3

62.9

68.0

62.0

62.8

67.7

65.5

65.3

62.6

64.5

63.1

61.6

69.7

62.2

63.8

62.1

65.7

66.7

64.4

63.4

61.1

58.8

62.0

64.6

65.6

64.1

62.9

61.0

59.9

60.0

77.0

80.0

60.9

65.1

62.2

64.7

58.4

67.8
No of Observations

45

1

9

4

14

2

7

7

49

1

2

2

17

2

8

11

9

11

3

4

28

31

29

14

3

24

5

3

1

33

3

23

8

1

3

1

1

1

15

8

4

39

4

4 
Table A1 (continued)

\section{Occupation Description}

\section{Code}

79

Social and welfare workers, except group

81 Economists

82 Psychologists

83 Statisticians and actuaries

91 Sports instructors and officials

92 Surveyors

93 Teachers (n.e.c.)

94 Technicians, medical and dental

95 Technicians, testing

96 Technicians (n.e.c.)

97 Therapists and healers (n.e.c.)

98 Veterinarians

99 Professional, technical and kindred workers (n.e.c.)

100

123

200

201

203

210

230

240

250

270

280

290

301

305

310

320

321

322

335

340

341

342

350

380

390

400

420

430

450

460

470

480

490

500

Farmers (owners and tenants)

Farm managers

Buyers and department heads, store

Buyers and shippers, farm products

Conductors, railroad

Inspectors, public administration

Managers and superintendents, building

Officers, pilots, pursers and engineers, ship

Officials and administrators (n.e.c.), public administration

Postmasters

Purchasing agents and buyers (n.e.c.)

Managers, officials, and proprietors (n.e.c.)

Attendants and assistants, library

Bank tellers

Bookkeepers

Cashiers

Collectors, bill and account

Dispatchers and starters, vehicle

Mail carriers

Messengers and office boys

Office machine operators

Shipping and receiving clerks

Stenographers, typists, and secretaries

Ticket, station, and express agents

Clerical and kindred workers (n.e.c.)

Advertising agents and salesmen

Demonstrators

Hucksters and peddlers

Insurance agents and brokers

Newsboys

Real estate agents and brokers

Stock and bond salesmen

Salesmen and sales clerks (n.e.c.)

Bakers

\section{Retirement Age \\ (Averg.)}

64.1

63.1

71.0

62.4

71.0

59.5

61.2

58.8

59.9

66.7

64.1

71.1

62.4

68.1

69.1

63.1

60.1

62.2

65.6

63.8

65.9

61.0

59.8

62.9

62.7

51.1

64.0

66.6

64.5

64.0

62.7

56.5

64.8

63.4

60.2

65.0

53.5

61.7

66.5

78.9

66.9

64.2

62.8

66.4

65.3

64.5

62.2
No of

Observations

13

4

1

2

1

4

78

13

38

4

5

3

91

157

18

12

10

3

11

29

3

46

2

18

660

2

1

21

27

1

7

24

23

14

33

13

3

189

10

4

14

41

10

47

16

186

7 
Table A1 (continued)

\section{Occupation Description \\ Code}

502 Bookbinders

503 Boilermakers

504 Brickmasons, stonemasons, and tile setters

505 Cabinetmakers

510 Carpenters

511 Cement and concrete finishers

512 Compositors and typesetters

513 Cranemen, derrickmen, and hoistmen

515 Electricians

522 Excavating, grading, and road machinery operators

523 Foremen (n.e.c.)

530 Glaziers

531 Heat treaters, annealers, temperers

533 Inspectors (n.e.c.)

534 Jewelers, watchmakers, goldsmiths, and silversmiths

540 Linemen and servicemen, telegraph, telephone, and pow€

541 Locomotive engineers

544 Machinists

545 Mechanics and repairmen, airplane

550 Mechanics and repairmen, automobile

551 Mechanics and repairmen, office machine

552 Mechanics and repairmen, radio and television

553 Mechanics and repairmen, railroad and car shop

554 Mechanics and repairmen (n.e.c.)

560 Millwrights

564 Painters, construction and maintenance

570 Pattern and model makers, except paper

573 Plasterers

$574 \quad$ Plumbers and pipe fitters

575 Pressmen and plate printers, printing

580 Rollers and roll hands, metal

581 Roofers and slaters

582 Shoemakers and repairers, except factory

583 Stationary engineers

585 Structural metal workers

590 Tailors and tailoresses

591 Tinsmiths, coppersmiths, and sheet metal workers

592 Tool makers, and die makers and setters

593 Upholsterers

594 Craftsmen and kindred workers (n.e.c.)

595 Members of the armed services

620 Asbestos and insulation workers

621 Attendants, auto service and parking

624 Brakemen, railroad

625 Bus drivers

632 Deliverymen and routemen

635 Filers, grinders, and polishers, metal

\section{Retirement Age \\ (Averg.)}

79.0

66.1

70.6

66.3

61.6

55.2

58.0

54.2

59.9

63.3

61.9

56.0

61.4

63.7

67.0

56.1

62.7

60.0

61.1

58.8

61.1

62.2

58.9

62.0

63.3

62.0

60.6

52.4

63.8

61.7

55.9

60.6

61.8

61.3

60.0

64.4

61.9

68.9

69.1

59.1

55.5

64.0

64.0

58.0

61.1

65.7

64.6
No of

\section{Observations}

1

3

8

9

75

5

1

7

58

24

113

3

2

14

7

28

5

26

10

67

12

16

7

143

6

34

3

3

37

7

2

5

6

15

5

6

14

11

9

23

17

3

16

5

51

11

7 
Table A1 (continued)

\section{Occupation Description}

Code

641 Furnacemen, smeltermen and pourers

643 Laundry and dry cleaning operatives

644 Meat cutters, except slaughter and packing house

650 Mine operatives and laborers

662 Oilers and greaser, except auto

670 Painters, except construction or maintenance

671 Photographic process workers

672 Power station operators

674 Sawyers

680 Stationary firemen

682 Taxicab drivers and chauffers

683 Truck and tractor drivers

685 Welders and flame cutters

690 Operative and kindred workers (n.e.c.)

720 Private household workers (n.e.c.)

730 Attendants, hospital and other institution

731 Attendants, professional and personal service (n.e.c.)

732 Attendants, recreation and amusement

740 Barbers, beauticians, and manicurists

750 Bartenders

753 Charwomen and cleaners

754 Cooks, except private household

760 Counter and fountain workers

762 Firemen, fire protection

763 Guards, watchmen, and doorkeepers

764 Housekeepers and stewards, except private household

770 Janitors and sextons

773 Policemen and detectives

780 Porters

781 Practical nurses

782 Sheriffs and bailiffs

784 Waiters and waitresses

785 Watchmen (crossing) and bridge tenders

790 Service workers, except private household (n.e.c.)

810 Farm foremen

820 Farm laborers, wage workers

910 Fishermen and oystermen

930 Gardeners, except farm, and groundskeepers

940 Longshoremen and stevedores

950 Lumbermen, raftsmen, and woodchoppers

970 Laborers (n.e.c.)

\section{Retirement Age \\ (Averg.)}

55.7

55.6

62.7

63.3

62.0

61.8

60.0

61.3

68.1

58.4

64.8

61.1

59.6

60.8

62.0

57.8

69.6

70.2

64.7

62.8

59.8

57.8

80.0

59.1

63.5

62.9

64.6

56.4

58.0

65.0

60.8

64.8

76.5

63.7

61.7

68.5

65.9

63.7

59.1

60.4

61.9
No of

\section{Observations}

5

4

24

10

3

8

1

5

3

4

31

241

22

320

17

14

13

12

6

10

6

37

1

28

95

16

254

40

3

1

12

8

3

51

2

44

4

69

3

4

201 
Table A2: Crosswalk Census Occupational Classification Scheme (1950) to ISCO-88 ISCO-88 Census Code

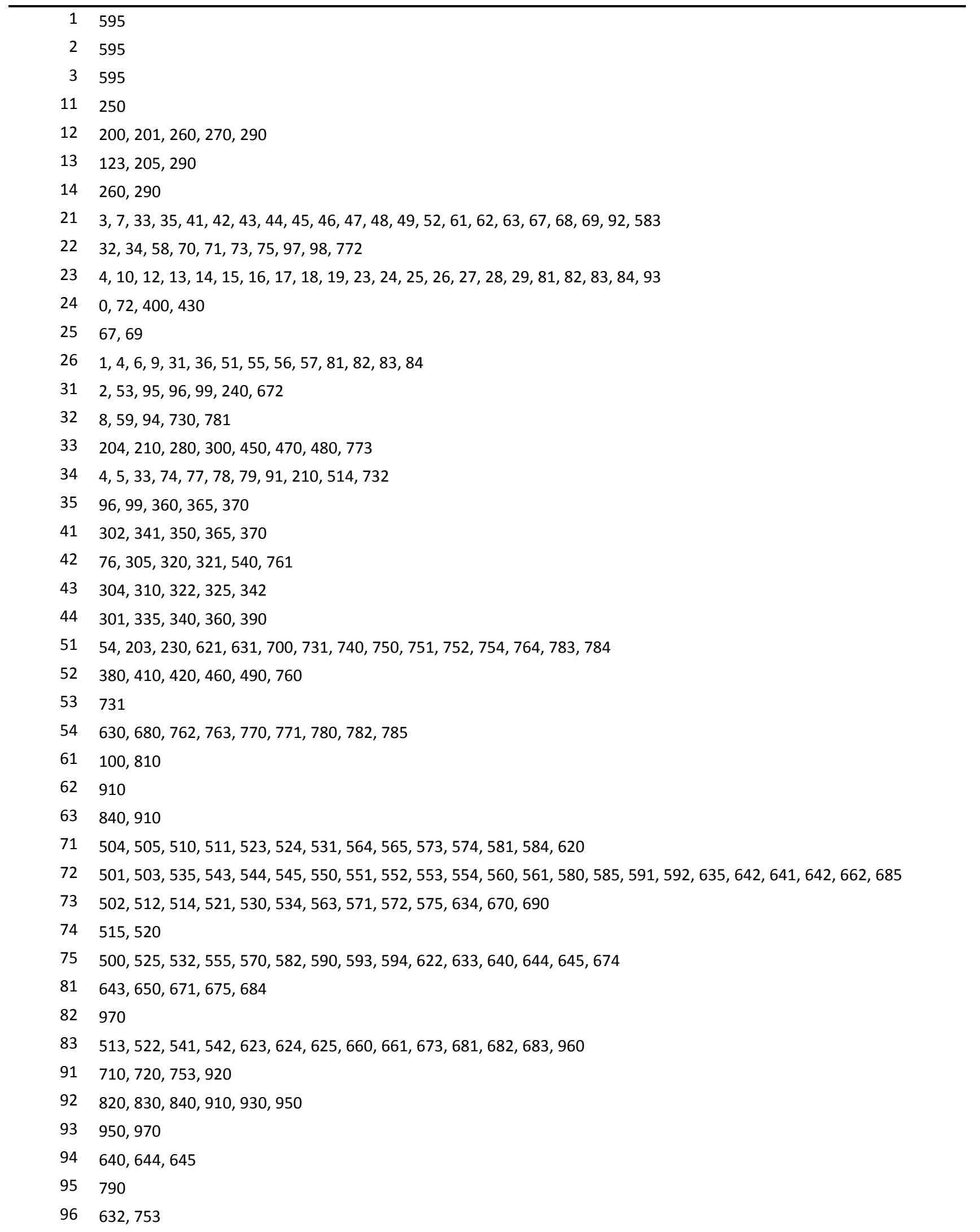




\section{Table A3: Occupational Class (ISCO-88) and Retirement Age}

\section{Code Description}

1 Commissioned armed forces officers

Retirement

Non-commissioned armed forces officers

3 Armed forces occupations, other ranks

56.7

11 Chief executives, senior officials and legislators

60.4

12 Administrative and commercial managers

61.2

13 Production and specialised services managers

Hospitality, retail and other services managers

61.3

62.3

21 Science and engineering professionals

62.4

Health professionals

61.0

23 Teaching professionals

Business and administration professionals

25 Information and communications technology professionals

31 Science and engineering associate professionals

32 Health associate professionals

33 Business and administration associate professionals

35 Information and communications technicians

41 General and keyboard clerks

42 Customer services clerks

43 Numerical and material recording clerks

44 Other clerical support workers

51 Personal service workers

52 Sales workers

53 Personal care workers

54 Protective services workers

61 Market-oriented skilled agricultural workers

62 Market-oriented skilled forestry, fishery and hunting workers

63 Subsistence farmers, fishers, hunters and gatherers

71 Building and related trades workers, excluding electricians 
Table A4: List of Available Data

\begin{tabular}{|c|c|c|c|c|}
\hline Country & ILO (Empl. by ISCO-88) & ILO (Empl. by Age) & OECD (Eff. Ret. Age) & Bloom et al (2009) \\
\hline Aruba & $x$ & $x$ & & \\
\hline Australia & & $x$ & $x$ & $x$ \\
\hline Austria & $x$ & $x$ & $x$ & $x$ \\
\hline Belgium & $x$ & $x$ & $x$ & $x$ \\
\hline Bulgaria & $x$ & $x$ & $x$ & \\
\hline Canada & & $x$ & $x$ & $x$ \\
\hline Chile & & $x$ & $x$ & $x$ \\
\hline Cyprus & $x$ & $x$ & $x$ & $x$ \\
\hline Czech Rep. & $x$ & $x$ & $x$ & \\
\hline Denmark & $x$ & $x$ & $x$ & $x$ \\
\hline Ecuador & $x$ & $x$ & & \\
\hline Egypt & $x$ & & & \\
\hline Estonia & $x$ & $x$ & $x$ & \\
\hline Finland & $x$ & $x$ & $\mathrm{x}$ & $\mathrm{x}$ \\
\hline France & $x$ & $x$ & $x$ & $x$ \\
\hline Gabon & $x$ & $x$ & & $x$ \\
\hline Germany & $x$ & $x$ & $x$ & $x$ \\
\hline Greece & $x$ & $x$ & $x$ & $x$ \\
\hline Hong Kong & $x$ & $x$ & & $x$ \\
\hline Hungary & $x$ & $x$ & $x$ & \\
\hline Iceland & $x$ & $x$ & $x$ & \\
\hline Iran & $x$ & $x$ & & \\
\hline Ireland & $x$ & $x$ & $x$ & $x$ \\
\hline Israel & & & $x$ & \\
\hline Italy & $x$ & $x$ & $x$ & $x$ \\
\hline Japan & & $x$ & $x$ & $x$ \\
\hline Korea & $x$ & $x$ & $x$ & $x$ \\
\hline Latvia & $x$ & $x$ & $x$ & \\
\hline Lithuania & $x$ & $x$ & $x$ & \\
\hline Luxembourg & $x$ & $x$ & $x$ & $x$ \\
\hline Malta & & $x$ & $x$ & $x$ \\
\hline Mauritius & $x$ & $x$ & & $x$ \\
\hline Mexico & & $x$ & $x$ & $x$ \\
\hline Mongolia & $x$ & & & \\
\hline Netherlands & $x$ & $x$ & $x$ & $x$ \\
\hline New Zealand & & $x$ & $x$ & $x$ \\
\hline Norway & & $x$ & $x$ & $x$ \\
\hline Pakistan & $x$ & $x$ & & \\
\hline Philippines & $x$ & & & \\
\hline Poland & $x$ & $x$ & $x$ & \\
\hline Portugal & $x$ & $x$ & $x$ & \\
\hline Romania & & $x$ & $x$ & \\
\hline Seychelles & $x$ & $x$ & & \\
\hline Slovakia & $x$ & $x$ & $x$ & \\
\hline Slovenia & $x$ & $x$ & $x$ & \\
\hline Spain & $x$ & $x$ & $x$ & $x$ \\
\hline Sweden & $x$ & $x$ & $x$ & $x$ \\
\hline Switzerland & $x$ & $x$ & $x$ & $x$ \\
\hline Thailand & $x$ & & & \\
\hline Turkey & & $x$ & $x$ & $x$ \\
\hline Uganda & $x$ & $x$ & & \\
\hline Ukraine & $x$ & $x$ & & \\
\hline United Kingdom & $x$ & $x$ & $x$ & $x$ \\
\hline United States & & $x$ & $x$ & $x$ \\
\hline
\end{tabular}




\section{Swiss National Bank Working Papers published since 2004:}

2004-1 Samuel Reynard: Financial Market Participation and the Apparent Instability of Money Demand

2004-2 Urs W. Birchler and Diana Hancock: What Does the Yield on Subordinated Bank Debt Measure?

2005-1 Hasan Bakhshi, Hashmat Khan and Barbara Rudolf: The Phillips curve under state-dependent pricing

2005-2 Andreas M. Fischer: On the Inadequacy of Newswire Reports for Empirical Research on Foreign Exchange Interventions

2006-1 Andreas M. Fischer: Measuring Income Elasticity for Swiss Money Demand: What do the Cantons say about Financial Innovation?

2006-2 Charlotte Christiansen and Angelo Ranaldo: Realized Bond-Stock Correlation: Macroeconomic Announcement Effects

2006-3 Martin Brown and Christian Zehnder: Credit Reporting, Relationship Banking, and Loan Repayment

2006-4 Hansjörg Lehmann and Michael Manz: The Exposure of Swiss Banks to Macroeconomic Shocks - an Empirical Investigation

2006-5 Katrin Assenmacher-Wesche and Stefan Gerlach: Money Growth, Output Gaps and Inflation at Low and High Frequency: Spectral Estimates for Switzerland

2006-6 Marlene Amstad and Andreas M. Fischer: Time-Varying Pass-Through from Import Prices to Consumer Prices: Evidence from an Event Study with Real-Time Data

2006-7 Samuel Reynard: Money and the Great Disinflation

2006-8 Urs W. Birchler and Matteo Facchinetti: Can bank supervisors rely on market data? A critical assessment from a Swiss perspective

2006-9 Petra Gerlach-Kristen: A Two-Pillar Phillips Curve for Switzerland

2006-10 Kevin J. Fox and Mathias Zurlinden: On Understanding Sources of Growth and Output Gaps for Switzerland

2006-11 Angelo Ranaldo: Intraday Market Dynamics Around Public Information Arrivals

2007-1 Andreas M. Fischer, Gulzina Isakova and Ulan Termechikov: Do FX traders in Bishkek have similar perceptions to their London colleagues? Survey evidence of market practitioners' views 
2007-2 Ibrahim Chowdhury and Andreas Schabert: Federal Reserve Policy viewed through a Money Supply Lens

2007-3 Angelo Ranaldo: Segmentation and Time-of-Day Patterns in Foreign Exchange Markets

2007-4 Jürg M. Blum: Why ‘Basel II’ May Need a Leverage Ratio Restriction

2007-5 Samuel Reynard: Maintaining Low Inflation: Money, Interest Rates, and Policy Stance

2007-6 Rina Rosenblatt-Wisch: Loss Aversion in Aggregate Macroeconomic Time Series

2007-7 Martin Brown, Maria Rueda Maurer, Tamara Pak and Nurlanbek Tynaev: Banking Sector Reform and Interest Rates in Transition Economies: Bank-Level Evidence from Kyrgyzstan

2007-8 Hans-Jürg Büttler: An Orthogonal Polynomial Approach to Estimate the Term Structure of Interest Rates

2007-9 Raphael Auer: The Colonial Origins Of Comparative Development: Comment. A Solution to the Settler Mortality Debate

2007-10 Franziska Bignasca and Enzo Rossi: Applying the Hirose-Kamada filter to Swiss data: Output gap and exchange rate pass-through estimates

2007-11 Angelo Ranaldo and Enzo Rossi: The reaction of asset markets to Swiss National Bank communication

2007-12 Lukas Burkhard and Andreas M. Fischer: Communicating Policy Options at the Zero Bound

2007-13 Katrin Assenmacher-Wesche, Stefan Gerlach, and Toshitaka Sekine: Monetary Factors and Inflation in Japan

2007-14 Jean-Marc Natal and Nicolas Stoffels: Globalization, markups and the natural rate of interest

2007-15 Martin Brown, Tullio Jappelli and Marco Pagano: Information Sharing and Credit: Firm-Level Evidence from Transition Countries

2007-16 Andreas M. Fischer, Matthias Lutz and Manuel Wälti: Who Prices Locally? Survey Evidence of Swiss Exporters

2007-17 Angelo Ranaldo and Paul Söderlind: Safe Haven Currencies 
2008-1 Martin Brown and Christian Zehnder: The Emergence of Information Sharing in Credit Markets

2008-2 Yvan Lengwiler and Carlos Lenz: Intelligible Factors for the Yield Curve

2008-3 Katrin Assenmacher-Wesche and M. Hashem Pesaran: Forecasting the Swiss Economy Using VECX* Models: An Exercise in Forecast Combination Across Models and Observation Windows

2008-4 Maria Clara Rueda Maurer: Foreign bank entry, institutional development and credit access: firm-level evidence from 22 transition countries

2008-5 Marlene Amstad and Andreas M. Fischer: Are Weekly Inflation Forecasts Informative?

2008-6 Raphael Auer and Thomas Chaney: Cost Pass Through in a Competitive Model of Pricing-to-Market

2008-7 Martin Brown, Armin Falk and Ernst Fehr: Competition and Relational Contracts: The Role of Unemployment as a Disciplinary Device

2008-8 Raphael Auer: The Colonial and Geographic Origins of Comparative Development

2008-9 Andreas M. Fischer and Angelo Ranaldo: Does FOMC News Increase Global FX Trading?

2008-10 Charlotte Christiansen and Angelo Ranaldo: Extreme Coexceedances in New EU Member States' Stock Markets

2008-11 Barbara Rudolf and Mathias Zurlinden: Measuring capital stocks and capital services in Switzerland

2008-12 Philip Sauré: How to Use Industrial Policy to Sustain Trade Agreements

2008-13 Thomas Bolli and Mathias Zurlinden: Measuring growth of labour quality and the quality-adjusted unemployment rate in Switzerland

2008-14 Samuel Reynard: What Drives the Swiss Franc?

2008-15 Daniel Kaufmann: Price-Setting Behaviour in Switzerland - Evidence from CPI Micro Data

2008-16 Katrin Assenmacher-Wesche and Stefan Gerlach: Financial Structure and the Impact of Monetary Policy on Asset Prices

2008-17 Ernst Fehr, Martin Brown and Christian Zehnder: On Reputation: A Microfoundation of Contract Enforcement and Price Rigidity 
2008-18 Raphael Auer and Andreas M. Fischer: The Effect of Low-Wage Import Competition on U.S. Inflationary Pressure

2008-19 Christian Beer, Steven Ongena and Marcel Peter: Borrowing in Foreign Currency: Austrian Households as Carry Traders

2009-1 Thomas Bolli and Mathias Zurlinden: Measurement of labor quality growth caused by unobservable characteristics

2009-2 Martin Brown, Steven Ongena and Pinar Yeșin: Foreign Currency Borrowing by Small Firms

2009-3 Matteo Bonato, Massimiliano Caporin and Angelo Ranaldo: Forecasting realized (co)variances with a block structure Wishart autoregressive model

2009-4 Paul Söderlind: Inflation Risk Premia and Survey Evidence on Macroeconomic Uncertainty

2009-5 Christian Hott: Explaining House Price Fluctuations

2009-6 Sarah M. Lein and Eva Köberl: Capacity Utilisation, Constraints and Price Adjustments under the Microscope

2009-7 Philipp Haene and Andy Sturm: Optimal Central Counterparty Risk Management

2009-8 Christian Hott: Banks and Real Estate Prices

2009-9 Terhi Jokipii and Alistair Milne: Bank Capital Buffer and Risk Adjustment Decisions

2009-10 Philip Sauré: Bounded Love of Variety and Patterns of Trade

2009-11 Nicole Allenspach: Banking and Transparency: Is More Information Always Better?

2009-12 Philip Sauré and Hosny Zoabi: Effects of Trade on Female Labor Force Participation

2009-13 Barbara Rudolf and Mathias Zurlinden: Productivity and economic growth in Switzerland 1991-2005

2009-14 Sébastien Kraenzlin and Martin Schlegel: Bidding Behavior in the SNB's Repo Auctions

2009-15 Martin Schlegel and Sébastien Kraenzlin: Demand for Reserves and the Central Bank's Management of Interest Rates

2009-16 Carlos Lenz and Marcel Savioz: Monetary determinants of the Swiss franc 
2010-1 Charlotte Christiansen, Angelo Ranaldo and Paul Söderlind: The Time-Varying Systematic Risk of Carry Trade Strategies

2010-2 Daniel Kaufmann: The Timing of Price Changes and the Role of Heterogeneity

2010-3 Loriano Mancini, Angelo Ranaldo and Jan Wrampelmeyer: Liquidity in the Foreign Exchange Market: Measurement, Commonality, and Risk Premiums

2010-4 Samuel Reynard and Andreas Schabert: Modeling Monetary Policy

2010-5 Pierre Monnin and Terhi Jokipii: The Impact of Banking Sector Stability on the Real Economy

2010-6 Sébastien Kraenzlin and Thomas Nellen: Daytime is money

2010-7 Philip Sauré: Overreporting Oil Reserves

2010-8 Elizabeth Steiner: Estimating a stock-flow model for the Swiss housing market

2010-9 Martin Brown, Steven Ongena, Alexander Popov, and Pinar Yeșin: Who Needs Credit and Who Gets Credit in Eastern Europe?

2010-10 Jean-Pierre Danthine and André Kurmann: The Business Cycle Implications of Reciprocity in Labor Relations

2010-11 Thomas Nitschka: Momentum in stock market returns: Implications for risk premia on foreign currencies

2010-12 Petra Gerlach-Kristen and Barbara Rudolf: Macroeconomic and interest rate volatility under alternative monetary operating procedures

2010-13 Raphael Auer: Consumer Heterogeneity and the Impact of Trade Liberalization: How Representative is the Representative Agent Framework?

2010-14 Tommaso Mancini Griffoli and Angelo Ranaldo: Limits to arbitrage during the crisis: funding liquidity constraints and covered interest parity

2010-15 Jean-Marc Natal: Monetary Policy Response to Oil Price Shocks

2010-16 Kathrin Degen and Andreas M. Fischer: Immigration and Swiss House Prices

2010-17 Andreas M. Fischer: Immigration and large banknotes

2010-18 Raphael Auer: Are Imports from Rich Nations Deskilling Emerging Economies? Human Capital and the Dynamic Effects of Trade 
2010-19 Jean-Pierre Danthine and John B. Donaldson: Executive Compensation: A General Equilibrium Perspective

2011-1 Thorsten Beck and Martin Brown: Which Households Use Banks? Evidence from the Transition Economies

2011-2 Martin Brown, Karolin Kirschenmann and Steven Ongena: Foreign Currency Loans Demand or Supply Driven?

2011-3 Victoria Galsband and Thomas Nitschka: Foreign currency returns and systematic risks

2011-4 Francis Breedon and Angelo Ranaldo: Intraday patterns in FX returns and order flow

2011-5 Basil Guggenheim, Sébastien Kraenzlin and Silvio Schumacher: Exploring an uncharted market: Evidence on the unsecured Swiss franc money market

2011-6 Pamela Hall: Is there any evidence of a Greenspan put?

2011-7 Daniel Kaufmann and Sarah Lein: Sectoral Inflation Dynamics, Idiosyncratic Shocks and Monetary Policy

2011-8 Iva Cecchin: Mortgage Rate Pass-Through in Switzerland

2011-9 Raphael A. Auer, Kathrin Degen and Andreas M. Fischer: Low-Wage Import Competition, Inflationary Pressure, and Industry Dynamics in Europe

2011-10 Raphael A. Auer and Philip Sauré: Spatial Competition in Quality, Demand-Induced Innovation, and Schumpeterian Growth

2011-11 Massimiliano Caporin , Angelo Ranaldo and Paolo Santucci de Magistris: On the Predictability of Stock Prices: a Case for High and Low Prices

2011-12 Jürg Mägerle and Thomas Nellen: Interoperability between central counterparties

2011-13 Sylvia Kaufmann: K-state switching models with endogenous transition distributions

2011-14 Sébastien Kraenzlin and Benedikt von Scarpatetti: Bargaining Power in the Repo Market

2012-01 Raphael A. Auer: Exchange Rate Pass-Through, Domestic Competition, and Inflation: Evidence from the 2005/08 Revaluation of the Renminbi

2012-02 Signe Krogstrup, Samuel Reynard and Barbara Sutter: Liquidity Effects of Quantitative Easing on Long-Term Interest Rates 
2012-03 Matteo Bonato, Massimiliano Caporin and Angelo Ranaldo: Risk spillovers in international equity portfolios

2012-04 Thomas Nitschka: Banking sectors' international interconnectedness: Implications for consumption risk sharing in Europe

2012-05 Martin Brown, Steven Ongena and Pinar Yeşin: Information Asymmetry and Foreign Currency Borrowing by Small Firms

2012-06 Philip Sauré and Hosny Zoabi: Retirement Age across Countries: The Role of Occupations 
Swiss National Bank Working Papers are also available at www.snb.ch, section Publications/Research Subscriptions or individual issues can be ordered at Swiss National Bank, Fraumünsterstrasse 8, CH-8022 Zurich, fax+41 4463181 14, E-mail library@snb.ch 